open $\bigcirc$ Access

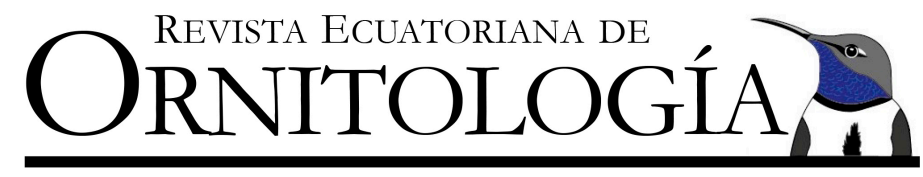

ARTICULO/ARTICLE

\title{
Fifth report of the Committee for Ecuadorian Records in Ornithology (CERO), with comments on some published, undocumented records
}

\author{
Juan F. Freile ${ }^{1,2, *}$, Scott Olmstead ${ }^{1,3}$, Nick Athanas ${ }^{1}$, Dušan M. Brinkhuizen ${ }^{1,4}$, Lelis Navarrete ${ }^{1,5}$, Jonas Nilsson ${ }^{1,6}$, Manuel \\ Sánchez-Nivicela ${ }^{1,2,7}$, Alejandro Solano-Ugalde ${ }^{1,8}$, Paul J. Greenfield ${ }^{1,9}$ \\ ${ }^{1}$ Comité Ecuatoriano de Registros Ornitológicos (CERO).E-mail: cero.ecuador@gmail.com \\ ${ }^{2}$ Red Aves Ecuador, Pasaje El Moro E4-216 y Norberto Salazar, Tumbaco. \\ ${ }^{3}$ Tropical Birding Tours, 113 Wind Tree Valley Rd, Parkton MD 21120, USA. \\ ${ }^{4}$ Rockjumper Birding Tours, Casilla Postal 17-07-9345, Quito. \\ ${ }^{5}$ Fray Leonardo Murialdo E9-208 y Los Jazmines, Quito. \\ ${ }^{6}$ Wildsumaco Lodge, Leonardo da Vinci 239 y Rafael Sanzio, edif. Oberer, Cumbayá. \\ ${ }^{7}$ Instituto Nacional de Biodiversidad, Pasaje Rumipamba N 341 y Av. De los Shyris, Quito. \\ ${ }^{8}$ Fundación Imaymana, Paltapamba 476, San Pedro del Valle, Nayón. \\ ${ }^{9}$ Mindo Cloudforest Foundation, Urb. El Bosque, 2da Etapa, calle Sexta \#161, edif. El Parque, Quito.
}

Editado por/Edited by: Elisa Bonaccorso

Recibido/Received: 11 Septiembre 2020 Aceptado/Accepted: 26 Noviembre 2020

Publicado en línea/Published online: 21 Diciembre 2020

\author{
Quinto reporte del Comité Ecuatoriano de Registros Ornitológicos (CERO), con comentarios sobre algunos \\ registros publicados no documentados
}

\section{Resumen}

Presentamos nuevos registros de distribución de aves del Ecuador que han sido evaluados por el Comité Ecuatoriano de Registros Ornitológicos (CERO) entre noviembre 2017 y junio 2019. Incluimos reportes de tres especies nuevas para Ecuador (Pelecanoides garnotii, Conirostrum margaritae, Piranga ludoviciana), cinco especies con primera documentación en Ecuador (Thaumastura cora, Anous minutus, Setophaga pensylvanica, S. virens, Spiza americana), dos especies con primera documentación en Galápagos (Oceanodroma hornbyi, Egretta tricolor), extensiones considerables de distribución de 15 especies (Amazilia amazilia, Aramus guarauna, Vanellus chilensis, Attagis gayi, Anous stolidus, Sterna hirundo, Thalasseus elegans, T. sandvicensis, Eurypyga helias, Mycteria americana, Plegadis falcinellus, Gampsonyx swainsonii, Rostrhamus sociabilis, Glaucidium peruanum, Thlypopsis sordida), nuevos reportes de 16 especies raras (Oressochen jubatus, Spatula cyanoptera, Podiceps major, Stercorarius longicaudus, Larus belcheri, Pelagodroma marina, Oceanodroma markhami, Egretta rufescens, Plegadis ridgwayi, Buteo swainsonii, Megascops koepckeae, Tyrannus albogularis, Setophaga castanea, Dolichonyx oryzivorus, Icterus chrysater, I. galbula) y registros adicionales de otras ocho especies. Se presentan los primeros registros en los Andes de Sterna hirundo y Thalasseus elegans, el primer registro de T. sandvicensis en el interior de la Amazonía y el primer registro de Piranga ludoviciana en Sudamérica. Finalmente, invalidamos registros previos de una especie (Pyrilia pyrilia) que aparecen en distintas publicaciones, rechazamos registros de seis especies sometidos a CERO en este periodo y discutimos seis registros previos publicados, no documentados, que podrían ser errados. CERO revisa y actualiza el listado nacional de aves, que en la actualidad alcanza las 1699 especies (1645 confirmadas y documentadas, 54 no documentadas).

Palabras clave: Comité Ecuatoriano de Registros Ornitológicos, extensiones de distribución, nuevos registros, registros hipotéticos.

\footnotetext{
Abstract

We present new distributional records of birds in Ecuador evaluated by the Committee for Ecuadorian Records in Ornithology (CERO), from November 2017 through June 2019. This report includes three species new to Ecuador (Pelecanoides garnotii, Conirostrum margaritae, Piranga ludoviciana), five species with first documented country records (Thaumastura cora, Anous minutus, Setophaga pensylvanica, S. virens, Spiza americana), two species with first documented Galápagos records (Oceanodroma hornbyi, Egretta tricolor), remarkable range extensions for 15 species
}

Freile, J.F., Olmstead, O., Athanas, N., Brinkhuizen, D.M., Navarrete, L., Nilsson, J., Sánchez-Nivicela, M., Solano-Ugalde, A., \& Greenfield, P.J. (2020). Fifth report of the Committee for Ecuadorian Records in Ornithology (CERO), with comments on some published, undocumented records. Revista Ecuatoriana de Ornitología, 6, 103133. 
(Amazilia amazilia, Aramus guarauna, Vanellus chilensis, Attagis gayi, Anous stolidus, Sterna hirundo, Thalasseus elegans, T. sandvicensis, Eurypyga helias, Mycteria americana, Plegadis falcinellus, Gampsonyx swainsonii, Rostrhamus sociabilis, Glaucidium peruanum, Thlypopsis sordida), new records of 16 rare species (Oressochen jubatus, Spatula cyanoptera, Podiceps major, Stercorarius longicaudus, Larus belcheri, Pelagodroma marina, Oceanodroma markhami, Egretta rufescens, Plegadis ridgwayi, Buteo swainsonii, Megascops koepckeae, Tyrannus albogularis, Setophaga castanea, Dolichonyx oryzivorus, Icterus chrysater, I. galbula) and additional records for eight species. We present the first records in the Andes of Sterna hirundo and Thalasseus elegans, the first record of T. sandvicensis in the inner Amazon basin, and the first South American record of Piranga ludoviciana. Finally, we invalidate previous records of Pyrilia pyrilia published in different sources, reject records of six species submitted to CERO, and discuss six previously published, undocumented records that might prove erroneous. CERO revises and updates the country bird list, which currently stands at 1699 species (1645 confirmed and documented; 54 undocumented).

Keywords: Committee for Ecuadorian Records in Ornithology, hypothetical records, new country records, range extensions.

\section{INTRODUCTION}

The unprecedented volume of information being compiled in publicly-accessible online archives provides exciting opportunities for rapid advances in knowledge on species distribution, especially in poorly studied regions. However, the public nature of such databases poses risks related to the accumulation and propagation of erroneous or imprecise data (Ball-Damerow et al., 2019; Bayraktarov et al., 2019). While large global records repositories such as www.macaulaylibrary.org and www.ebird.org provide increasingly convenient access for a range of data contributors and consumers, this same ease of use presents significant challenges for review and validation of reports. To preserve high-quality ornithological records, increased collaboration between these global data-managing initiatives and local, national and/or regional committees is needed (Freile et al., 2018).

The growing popularity and accessibility of online archives also create a need for records committees to reevaluate their processes and guidelines. To remain relevant, records committees must keep pace with rapid data accumulation and embrace an increasing number of observers in megadiverse countries like Ecuador, where ornithology and bird-observation are growing. The Committee for Ecuadorian Records in Ornithology (CERO), which aims to review novel records in this country, is paying increased attention to records broadcasted or archived online only. With four reports published to date (Freile et al., 2013, 2017, 2019a; Nilsson et al., 2014), CERO has presented 29 new country records ( 23 species and 6 subspecies) and first documented records for 27 species, alongside significant range extensions for more than 100 species, including new records of several country rarities. Likewise, the committee has made a concerted effort to remove species previously included in Ecuador's species list as a result of erroneous or imprecise information (see Freile et al., 2019a). We hope that by establishing a single, validated, and standardized species list, we can facilitate further development of ornithology, education, birding, and conservation alike (Freile et al., 2018).

This report presents new records evaluated by CERO since its fourth report, as well as a brief revision of some previously published, undocumented records. The result is a newly updated official checklist containing a total of 1699 species (54 undocumented) (Freile et al., 2020). The complete list is published on CERO's webpage: www.ceroecuador.wordpress.com.

\section{METHODS}

CERO receives and reviews records of rare species, new country records, and/or significant range extensions submitted voluntarily by their authors through CERO's webpage or e-mail address (cero.ecuador@gmail.com). Further, committee members regularly discover reports of 'rarities' at social media and public databases such as eBird, and then requests observers to submit their records for review, or to authorize CERO to evaluate them.

The national country checklist and a list of 'most-wanted' species are published on CERO's webpage, allowing observers to determine the status of the birds of Ecuador (www.ceroecuador.wordpress.com). New country records are evaluated and accepted by unanimous vote, while first documentation, undocumented records of 
previously hypothetical species, and significant range extensions are accepted by majority vote. For this report, CERO reviewed 74 reports submitted from November 2017 through June 2019, of records dating from October 1992 through June 2019.

Reports evaluated in this compilation were generated using varied survey protocols and documentation techniques, including sounds, and photographs, but some include undocumented observations (i.e., records lacking voucher documentation like specimens, photographs, video-recording, audio-recording, or field sketches and notes). Most sound-recordings were deposited by observers in Xeno-Canto or Macaulay Library online archives (www.xeno-canto.org; http://www.macaulaylibrary.org), for which a XC or ML code (respectively) and appropriate citation are provided in the species accounts. Photographs are stored in the CERO archives, some are published online, and the most relevant are published in this report. Locality coordinates and elevation are provided in Table 1; Figures 1-6 show documentary evidence for these records. New country records are marked with an asterisk in the species accounts. Taxonomy and species sequence follow the August 2019 version of the Clements checklist of the birds of the world (Clements et al., 2019).

\section{RESULTS AND DISCUSSION}

\section{Orinoco Goose Oressochen jubatus}

Orellana Province, near Yasuní National Park's clay licks, on the south bank of Río Napo, 15 January 2015, P. Petrus (photo).

Two birds were observed and photographed on a sandy river bank (Fig. 5a; Petrus, 2015). There are few records of this species in Ecuador, mostly confined to the lower portion of the Río Pastaza (Freile \& Restall, 2018), with even sparser records along the Río Napo, the last known to us dating back to 1992-1993 (L. Navarrete, pers. observ.). There is one exceptional record at Ecuasal Pacoa, of a single individual observed by B. Haase on an undetermined date between 1992-1995 (B. Haase, in litt., July 2020).

\section{Cinnamon Teal Spatula cyanoptera}

Imbabura Province, Lago San Pablo, 4 January 2017, C. Vogt (photo).

One adult male was observed and photographed (Fig. 5b; Vogt, 2017) at a water treatment pond adjacent to Lago San Pablo. As the drake is shown swimming with its belly submerged, we cannot determine with 100\% certainty whether it belongs to the boreal migrant subspecies Spatula cyanoptera septentrionalium or the very rare and declining Andean subspecies $S$. c. borreroi. The latter subspecies differs from the former by its large blackish spots mainly on the belly. However, the visible portion of the lower breast is plain cinnamon, suggesting that it belongs to the boreal migrant subspecies (Fjeldså \& Krabbe, 1990); the January date also fits for a boreal migrant.

The Andean subspecies is considered extinct in Ecuador (Freile et al., 2019b), where it presumably bred (Fjeldså \& Krabbe, 1990). The number of records of $S$. cyanoptera in Ecuador has increased steadily in recent years (Camacho \& Wilson, 2011; Freile et al., 2013; Nilsson et al.2014; Haase, 2019), all pertaining to boreal/austral migrants or vagrants.

\section{Northern Pintail Anas acuta}

Esmeraldas Province, Las Peñas, 24 November 2016, R. Ahlman (photo).

Manabí Province, La Segua, 30 December 2016, R. Ahlman (photo).

The Las Peñas record involved two adults of undetermined sex observed and photographed resting on a muddy bank, along with other migratory waterfowl and waders (Fig. 5c). The La Segua record involved a single adult observed one month later, swimming in open water (Ahlman, 2016). This boreal species was recorded for the first time in Ecuador as recently as June 2012 (Freile et al., 2013). Ecuador's southernmost record corresponds to a female photographed by E. Reyes at Pacoa (Haase, 2019). 
Table 1: Localities of records submitted to the Committee for Ecuadorian Records in Ornithology (CERO) between November 2017 and June 2019. Asterisk indicates localities mentioned in the text accounts, not locality records.

\begin{tabular}{|c|c|c|}
\hline Locality, province & Coordinates & Elevation (m) \\
\hline Aguayacu Ecolodge, Napo* & $-0.8963 /-77.7679$ & 710 \\
\hline Borja bypass, Napo & $-0.4375 /-77.8517$ & 1770 \\
\hline Cerro Mongus, Carchi* & $0.4373 /-77.859$ & c. 3300 \\
\hline Charco Vicente, Esmeraldas* & $0.683 /-78.917$ & c. 300 \\
\hline Colonia 24 de Mayo, Pastaza & $-1.40025 /-78.059$ & 1277 \\
\hline Cristóbal Colón, Esmeraldas* & $0.454 /-79.158$ & 150 \\
\hline Ecuasal Mar Bravo, Santa Elena & $-2.2167 /-80.967$ & 0 \\
\hline Ecuasal Pacoa, Santa Elena & $2.1008 /-80.7435$ & 0 \\
\hline El Carmen de Putumayo, Sucumbíos & $0.118 /-75.856$ & 220 \\
\hline El Carrizal, parroquia Urbina, Carchi & $0.7866 /-77.71135$ & 2950 \\
\hline El Empalme, Loja* & $-4.1478 /-79.8569$ & 760 \\
\hline Estero Capulí, Río Ónzole, Esmeraldas* & c. $-0.771 /-79.075$ & c. 50 \\
\hline Estero Pote, Esmeraldas* & $0.8284 /-78.72201$ & 200 \\
\hline Isla Española, near, Galápagos & $-1.3391 /-89.6570$ & 0 \\
\hline Isla de la Plata, Manabí & $-1.2687 /-81.0652$ & 0 \\
\hline Isla Floreana, off south, Galápagos & $-1.6782 /-90.5412$ & 0 \\
\hline Isla San Cristóbal, near, Galápagos & $-1.2030 /-89.6538$ & 0 \\
\hline Isla San Cristóbal, pelagic to Isla Española, Galápagos & $-1.11623 /-89.6547$ & 0 \\
\hline Jardín Botánico de Quito, Pichincha & $-0.183 /-78.483$ & 2800 \\
\hline Jimbura, 3-4 km W, Loja & $-4.6134 /-79.472$ & 2250 \\
\hline Kapawi, Pastaza* & $-2.75 /-76.75$ & 200 \\
\hline Lago San Pablo, Imbabura & $0.2183 /-78.2351$ & 2660 \\
\hline Laguna Yaguarcocha, Imbabura & $0.3666 /-78.0833$ & 2200 \\
\hline La Chocolatera, Santa Elena & $-2.189 /-81.011$ & 0 \\
\hline La Josefina, Pichincha & $-0.0011 /-78.1411$ & 2890 \\
\hline La Segua, Manabí & $-0.713 /-80.201$ & 2 \\
\hline La Selva, Sucumbíos* & $-0.416 /-76.133$ & 250 \\
\hline La Tembladera, El Oro & $-3.4904 /-79.9967$ & 13 \\
\hline
\end{tabular}


Las Peñas, 10 km N, Esmeraldas

Limpiopungo, Pichincha

La Lobería, San Cristóbal, Galápagos

Loja, campus UTPL, Loja

Los Laurales de Guasaganda, Cotopaxi

Manantiales, Manabí

Manta-Montecristi area, Manabí

Maxus road, Orellana*

Meseta de Gualpi, Carchi

Milagro, Guayas

Mindo, Pichincha

Nuevo Paraíso Road, Zamora Chinchipe*

Nuevo Rocafuerte, Orellana

Nuevo Rocafuerte (river islands), Orellana

Pachijal, Pichincha

Paquisha, Zamora Chinchipe

Parque Guápulo, Pichincha

Perucho, Pichincha*

Pedro Vicente Maldonado, near, Pichincha*

Playa de Oro, Esmeraldas

Puerto Engabao, Guayas

Puerto López, Manabí

Puerto Quito, Pichincha*

Puembo Birding Garden, Pichincha*

Punta Cormorant, Galápagos

Punta Galera, off, Esmeraldas

Represa Tahuín, El Oro*

Reserva Buenaventura, El Oro

Reserva Copalinga, Zamora Chinchipe

Reserva Jatun Sacha, Napo*

Reserva Mashpi Shungo, Pichincha

Reserva Otongachi, Pichincha

\begin{tabular}{|c|c|}
\hline $1.0996 /-79.15205$ & 0 \\
\hline$-0.6428 /-78.4848$ & 3890 \\
\hline$-0.9221 /-89.612$ & 0 \\
\hline$-3.987 /-79.1995$ & 2200 \\
\hline$-0.8357 /-79.2053$ & 600 \\
\hline$-1.24042 /-80.7529$ & c. 50 \\
\hline$-1.0274 /-80.656$ & 100 \\
\hline$-0.473 /-76.574$ & 250 \\
\hline $0.8612 /-78.2247$ & 2150 \\
\hline$-2.119 /-79.6002$ & 3 \\
\hline$-0.054 /-78.7786$ & 1250 \\
\hline$-4.26001 /-78.6474$ & c. 1000 \\
\hline$-0.92677 /-75.4017$ & 190 \\
\hline$-0.92105 /-75.3866$ & 190 \\
\hline $0.1607 /-78.9351$ & 520 \\
\hline$-3.9326 /-78.6764$ & 820 \\
\hline$-0.1978 /-78.4726$ & 2600 \\
\hline $0.10917 /-78.4242$ & 1800 \\
\hline $0.133 /-79.133$ & c. 500 \\
\hline $0.84847 /-78.7822$ & c. 150 \\
\hline$-2.5781 /-80.48406$ & 0 \\
\hline$-1.56194 /-80.8164$ & 0 \\
\hline $0.1188 /-79.2666$ & 145 \\
\hline$-0.1657 /-78.3612$ & 2430 \\
\hline$-1.22744 /-90.4257$ & 0 \\
\hline $0.81627 /-80.0471$ & 0 \\
\hline$-3.6354 /-80.0017$ & 110 \\
\hline$-3.6492 /-79.7615$ & c. 500 \\
\hline$-4.0915 /-78.9581$ & 950 \\
\hline$-1.0665 /-77.6183$ & 430 \\
\hline $0.1824 /-78.91215$ & 520 \\
\hline$-0.32125 /-78.9516$ & 850 \\
\hline
\end{tabular}




\begin{tabular}{lcr} 
Reserva Tamandua, Pastaza* & $-1.315 /-77.9695$ & 950 \\
Reserva Yanacocha, Pichincha & $-0.1119 /-78.5848$ & $c .3500$ \\
Río Bigal, near, Orellana* & $-0.5235 /-77.4198$ & $c .900$ \\
Río Napo, 10-15 km downriver from Coca, Orellana & $-0.444 /-76.7323$ & 275 \\
Río Napo, clay licks near Yasuni National Park control, & $-0.52736 /-76.3776$ & 220 \\
Orellana & & \\
Río Quijos Ecolodge, Napo & $-0.3925 /-77.81619$ & 1500 \\
Río Silanche, Pichincha* & $0.144 /-79.141$ & 400 \\
Sabanillas, Zamora Chinchipe & $-3.976 /-79.026$ & $c .1600$ \\
Salto del Bravo, Esmeraldas* & $0.667 /-78.967$ & $c .200$ \\
Same, Esmeralda** & $0.8491 /-79.9269$ & 0 \\
Shiripuno, Orellana & $-1.10368 /-76.7317$ & 240 \\
Siguin, Pastaza* & $-1.63804 /-77.8406$ & 1040 \\
Sumaco Road, Napo* & $-0.6843 /-77.6023$ & $c .1200$ \\
Volcán Cayambe, Pichincha* & $0.025 /-78.025$ & $c .4000$ \\
Volcán Chiles, s slope, Carchi & $0.8059 /-77.9349$ & 4282 \\
\hline
\end{tabular}

\section{Great Grebe Podiceps major}

El Oro Province, La Tembladera, 12 June 2015, A. Solano-Ugalde, J. Freile, M. Sánchez-Nivicela, R. Ahlman (photo).

Manabí Province, Isla de la Plata, 17 December 2017, B. Wilcox (photo).

A single adult of undetermined sex was observed and photographed (Fig. 5d) in calm water at Isla de la Plata's arriving bay, where water is calm (Wilcox, 2017). The La Tembladera record involved one adult male photographed once, and observed during the remainder of the day swimming and diving in open waters at the eastern end of this freshwater wetland. There are previous published records from La Tembladera (Pozo-Zamora et al., 2015).

The number of records of $P$. major in Ecuador has increased in recent years, even though it was first observed as recently as 2005 (Haase, 2011). Most records have involved non-breeding individuals, but breeding has now been reported at Tahuín dam, El Oro province (Pozo-Zamora et al., 2015).

\section{Peruvian Sheartail Thaumastura cora}

Loja Province, 3 km west of Jimbura, 12 June 2018, R. Ahlman, D. Jumbo (photo).

One adult male and one adult female were observed in a patch of semi-humid scrub surrounded by degraded land (Fig. 2a; Ahlman, 2018b). This observation represents the first documented Ecuadorian record, where a single previous sighting in presumably similar habitat existed (Ridgely \& Greenfield, 2001). Two adult males and one female-plumaged bird were observed at the same scrub patch on 21 April 2019 by J. Freile and B. Tinoco (Tinoco, 2019), and on 24 May 2019 by D. Pacheco and A. Carrasco (Pacheco, 2019), with additional recent records from the same general area (eBird, 2020). 


\section{Amazilia Hummingbird Amazilia amazilia}

Zamora Chinchipe Province, Copalinga, 10 November 2017, A. Solano-Ugalde.

One adult was observed feeding on Stachytarpheta (Verbenaceae) flowers and then being actively chased away by one Sparkling Violetear Colibri coruscans. There are a handful of additional records of this species from Copalinga, in December 2007 and November 2011 (as reported in the submission form; Fig. 4a), and March 2012 (Geoffray, 2012) and October 2015 (Hertzog, 2015).

There are very few previous records from the eastern slope of the Andes, including observations above Zamora and nearby Sabanilla (Ridgely \& Greenfield, 2001). These records may have involved wanderers from nearby highlands. Although most previous records do not indicate subspecific identity, the photographic record from 2011 corresponds to A. amazilia alticola, which ranges in the drier valleys and highlands of Loja and El Oro provinces. Amazilia a. alticola was suggested to be a separate species by Weller (2000), but this possibility was rejected by Krabbe \& Ridgely (2010). The species is transferred to the genus Amazilis by Remsen et al., (2020).

\section{Limpkin Aramus guarauna}

Pichincha Province, Reserva Mashpi Shungo, 18 September 2017, A. Solano-Ugalde (photo).

Zamora Chinchipe Province, Paquisha, 20 July 2017, F. Castillo (photo).

A single individual was observed at a fish pond in Mashpi Shungo, where it remained for $c$. 1 week before departing (Fig 4b). Additionally, one adult was observed in tall marshy grassland adjacent to the Nangaritza River, on the outskirts of Paquisha (Fig. 4c). These records are the highest in elevation (520 and $820 \mathrm{~m}$ a.s.l., respectively) known to date, on either slope of the Andes, and fall outside the core distributional range of this species that, notwithstanding, is highly prone to wandering (Freile \& Restall, 2018). This species might be spreading towards the northern lowlands and Andean foothills of western Ecuador, considering the number of recent records (eBird, 2020).

\section{Southern Lapwing Vanellus chilensis}

Zamora Chinchipe Province, Paquisha, 5 August 2017, F. Castillo (photo).

Up to eight individuals dwell at various sites in and around Paquisha, suggesting a small established population in this recently colonized location. It seems unlikely that this vocal and conspicuous species might have remained overlooked in the area (Ridgely \& Greenfield, 2001), and in fact, there were no records along the Río Nangaritza drainage until at least 2012 (Freile et al., 2014). The Paquisha outpost is representative of the rapid spread of this species into the Amazonian foothills of Ecuador (Ridgely \& Greenfield, 2001; McMullan \& Navarrete, 2017; Freile \& Restall, 2018). This species is also rapidly spreading throughout the Pacific lowlands and locally up into the Interandean valleys (Freile \& Restall, 2018). There are a handful of more recent (20172020) records from the Río Zamora and Río Upano basins in southern Ecuador (eBird, 2020), including a record that predates the one reported to CERO by F. Castillo (Rasmussen, 2017).

\section{Rufous-bellied Seedsnipe Attagis gayi}

Carchi Province, southern part of Volcán Chiles, 12 April 2018, E. Taimal (photo).

One pair was observed at close range in a transitional habitat between paramo and barren rocky areas with sparse vegetation (Fig. 4e). This represents the northernmost record of this species in the Andes (Fjeldså \& Krabbe, 1990), $90 \mathrm{~km}$ north of its nearest known locality (Volcán Cayambe). Attagis gayi is represented in Ecuador by the highly isolated, endemic subspecies A. gayi latreillii (Fjeldså \& Krabbe, 1990; Freile \& Restall, 2018). Volcán Chiles is situated on Ecuador's border with Colombia. Thus, the species undoubtedly occurs on its Colombian slopes as well.

\section{Long-tailed Jaeger Stercorarius longicaudus}

Santa Elena Province, La Chocolatera, 6-7 November 2015, 30 October 2017, R. Ahlman.

Three individuals were observed on 2 consecutive days; two adults and one dark-morph juvenile on November 2015, and one dark-morph juvenile on October 2017. Two of the jaegers were harassing or attacking terns and 
obtaining prey on one occasion (Ahlman, 2015c). Details provided by the author are brief, but the description of small size, slender shape, white shafts on outer primaries, rather short bill, and two-toned upperparts are adequate to rule out Parasitic Jaeger Stercorarius parasiticus, which was also observed (Ahlman, 2015c; 2015d; 2017).

There are few records of $S$. longicaudus from coastal Ecuador, including previous observations at La Chocolatera (Freile \& Restall, 2018) and the Santa Elena peninsula area (Haase, 2011), where the first documented record from mainland Ecuador was obtained by R. Ahlman in September 2014 (Freile et al., 2017).

A

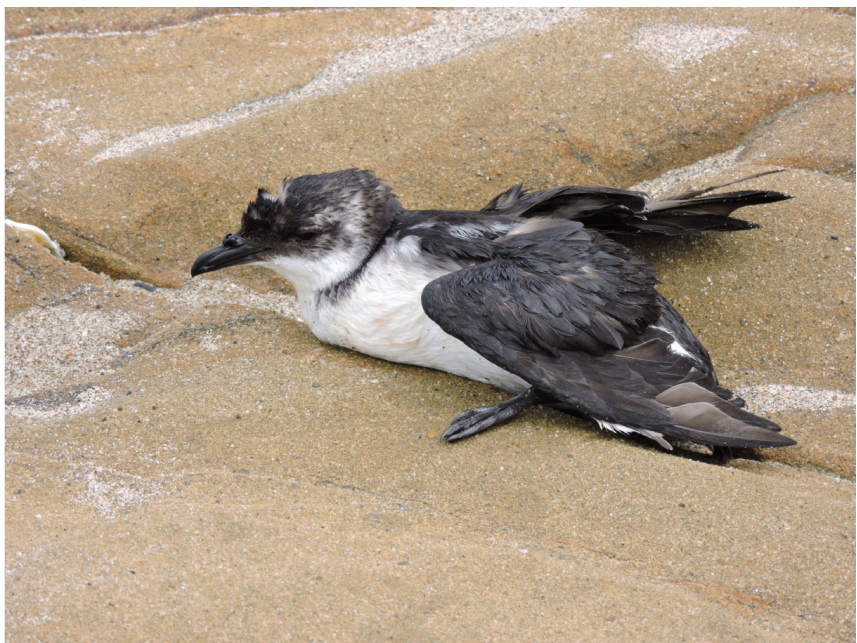

B

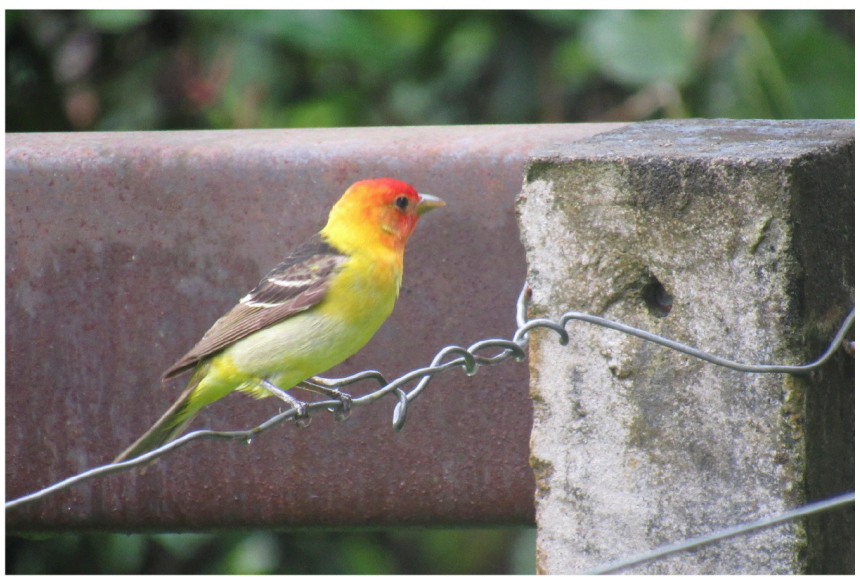

C

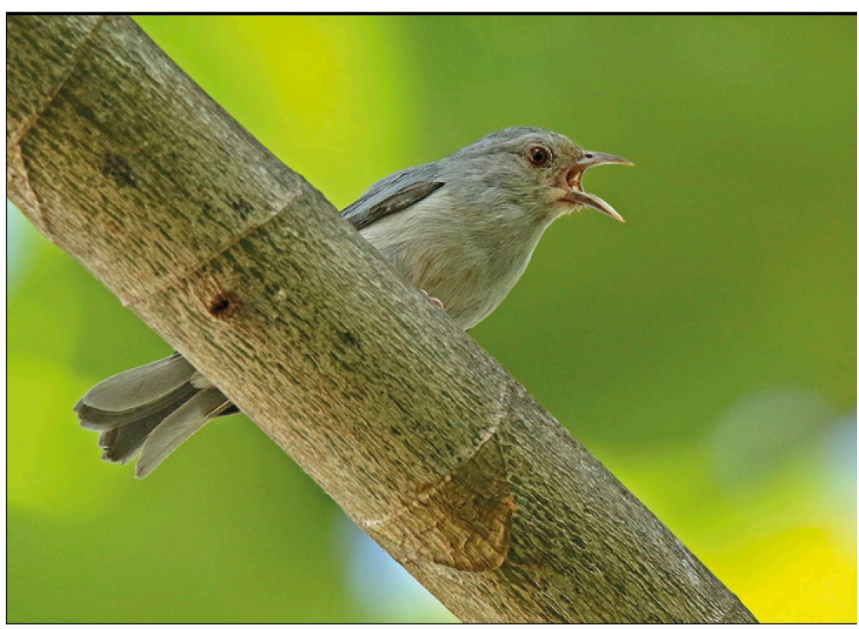

Figure 1: New country records for Ecuador. a) Pelecanoides garnotii, Puerto Engabao, Guayas province (F. Pásara); b) Piranga ludoviciana, Reserva Otongachi, Pichincha province (A. G. Simbaña); c) Conirostrum margaritae, island near Nuevo Rocafuerte, Río Napo, Orellana province (R. Ahlman; ML 100220791). 


\section{Belcher's Gull Larus belcheri}

Manabí Province, Puerto López, 19 November 2017, S. M. Plúa, A. Plaza (photo).

Santa Elena Province, Lagunas de Ecuasal at Mar Bravo, 24 June 2018, P. Bourdin (photo).

One adult in breeding plumage was observed and photographed at Puerto López on the beach near the fish market (Fig. 5e). Another adult in non-breeding/basic plumage was photographed in a sandy ditch at Ecuasal Mar Bravo (Fig. 5f; Bourdin, 2018). The species has been recorded in Ecuador in September, November, January, May, and June (Haase, 2011; eBird, 2020). The number of records has increased in recent years (Haase, 2019), but the Puerto López individual is the first reported in breeding/alternate plumage. The species has not been found breeding in Ecuador to date.

\section{Brown Noddy Anous stolidus}

Esmeraldas Province, off Punta Galera, 24 February 2016, R. Ahlman, D. Jumbo (photo).

Three adults were observed and one of them photographed (Fig. 4f) on a pelagic day trip off Punta Galera. Another individual was observed from shore on 23 February 2016 at Same, Esmeraldas by the same observers, who also report a sight record from December 2015 at Punta Galera. Previously recorded from Santa Elena peninsula only (Camacho \& Torres, 2011; Haase, 2019) in February (contra Freile \& Restall, 2018), with 17 individuals reportedly observed in 2010-2019 from La Chocolatera by Haase (2019).

Camacho \& Torres (2011) identified the bird they observed as probable A. s. galapagensis, due to its dark brown plumage with a paler, but not well-defined forecrown and grayish-brown rearcrown. However, the noddies observed at Punta Galera might correspond to A. s. ridgwayi, which is warmer brown, with a more contrasting whitish crown and paler forecrown (Howell \& Zufelt, 2019). This record would represent the first record of $A$. s. ridgwayi in Ecuadorian waters, but further documentation is needed to confirm it. This subspecies likely breeds on the Malpelo Islands, Colombia (López-Victoria \& Estela, 2007), c. $380 \mathrm{~km}$ north-northwest of Punta Galera.

\section{Black Noddy Anous minutus}

Santa Elena Province, La Chocolatera, 7 July 2015, R. Ahlman (photo).

One individual was observed between $6 \mathrm{~h} 45-8 \mathrm{~h} 35$ near the rocky coast, momentarily joining a large feeding aggregation of seabirds (Fig. 2b). There is one previous record of a dark noddy from the Santa Elena peninsula area, first published with unconfirmed identification (Haase, 2011), but later identified as Anous minutus (Haase, 2019). The July 2015 record becomes the second record of the species and first documented evidence for Ecuador (cf. Ahlman, 2015b).

\section{Common Tern Sterna hirundo}

Imbabura Province, Laguna Yaguarcocha, 24 November 2018, E. Obando, J. Meneses, M. Aragón (photo).

One bird in non-breeding plumage was observed distantly in the early morning and was later relocated and photographed after a considerable closer approach (Fig. 4g). It was resting on a buoy only $20 \mathrm{~m}$ from an Elegant Tern Thalasseus elegans (see below). There are few inland records of Sterna hirundo in Ecuador, this one being the first in the Ecuadorian Andes and the highest in elevation (Freile \& Restall, 2018) at $2200 \mathrm{~m}$ a.s.l. It is also the only record in the entire Andean cordillera known to us (eBird, 2020).

\section{Elegant Tern Thalasseus elegans}

Imbabura Province, Laguna Yaguarcocha, 24 November 2018, E. Obando, J. Meneses, M. Aragón (photo).

One individual in non-breeding plumage was observed near the $S$. hirundo reported above (Fig. 4h). It was first observed flying over a Cattle Egret Bubulcus ibis breeding colony and later perched on a buoy, where it was photographed. This is the first documented record of Thalasseus elegans in the Andes of Ecuador (Freile \& Restall, 2018), but there is one additional record with no date or locality details (Ridgely \& Greenfield, 2020). As far as we are aware, this is the first documented record from the entire Andes. 


\section{Sandwich Tern Thalasseus sandvicensis}

Orellana Province, $c$. 10-15 km downriver from Coca on the Río Napo, 8 January 2018, B. Nooner (photo).

One adult in non-breeding plumage was observed and photographed flying close to sand bars in the middle of the river at 14h30 (Fig. 4i; Nooner, 2018). This is the first record from Amazonian Ecuador (Freile \& Restall, 2018) and, as far as we know, from the entire inner Amazon basin (eBird, 2020).

\section{Sunbittern Eurypyga helias}

Napo Province, Río Quijos Ecolodge, 21 October 2018, C. A. Vásquez (photo).

One bird was photographed walking over boulders on the Río Quijos (Fig. 4j). This record, at c. $1500 \mathrm{~m}$ a.s.l., is one of the highest in elevation from eastern Ecuador (Freile \& Restall, 2018; Cadena-Ortiz et al., 2018). The photographed bird belongs to the subspecies Eurypyga helias meridionalis (grayish back and upperwing coverts), a foothill subspecies only recently observed for the first time in Ecuador in 2008 (Freile et al., 2013) and known from just two additional localities (Freile \& Restall, 2018; Cadena-Ortiz et al., 2018). The fact that this form maintains its integrity despite being possibly in contact with the nominate form of the Amazonian lowlands suggests that it might deserve species status, but more information is needed to determine whether these two subspecies actually overlap.

\section{White-faced Storm-Petrel Pelagodroma marina}

Galápagos Province, near Española Island coast to the north, 15 June 2018, A. Jaramillo (photo).

Galápagos Province, pelagic between San Cristóbal and Española, 12 July 2014, A. Bruun Kristensen (photo).

Two separate individuals were seen in pelagic waters between San Cristóbal and Española (Figs. 5g, 5h). There are few Galápagos records, where the species is considered as vagrant (Wiedenfeld, 2006; McMullan \& Navarrete, 2017). The paucity of records might be explained partially by poor knowledge of oceanic birds and limited pelagic observation activity (Wiedenfeld, 2006). Dates suggest non-breeding austral visitors (Howell \& Zufelt, 2019).

\section{Markham's Storm-Petrel Oceanodroma markhami}

Galápagos Province, between San Cristóbal Island and Española Island, 28 July 2017, A. Jaramillo (photo).

Galápagos Province, near San Cristóbal Island coast to the south, 16 August 2008, J. Gilliam (photo).

Two birds were seen in pelagic waters between San Cristóbal and Española on separate dates (Figs. 5i, 5j). There are few Galápagos records of this non-breeding austral vagrant (Wiedenfeld, 2006; McMullan \& Navarrete, 2017). However, as with previous species, the scarcity of records might partially be explained by limited pelagic work.

\section{Ringed Storm-Petrel Oceanodroma hornbyi}

Galápagos Province, off south Floreana Island, 8 November 2017, R. Tizard (photo).

A single bird was observed and photographed in pelagic waters off Floreana (Fig. 3a). This represents the first documented record from the Galápagos (Freile et al., 2020), where the species is known from two published sight records (Wiedenfeld, 2006) on an unexpected date for an austral breeder (April 1967). Records in waters off mainland Ecuador also include unexpected dates (July 2007, February 2008; see Freile et al., 2013; Nilsson et al., 2014), suggesting that the temporal distribution patterns of this species, which is confined to the Humboldt Current, are more complex than previously acknowledged (Howell \& Zufelt, 2019). 

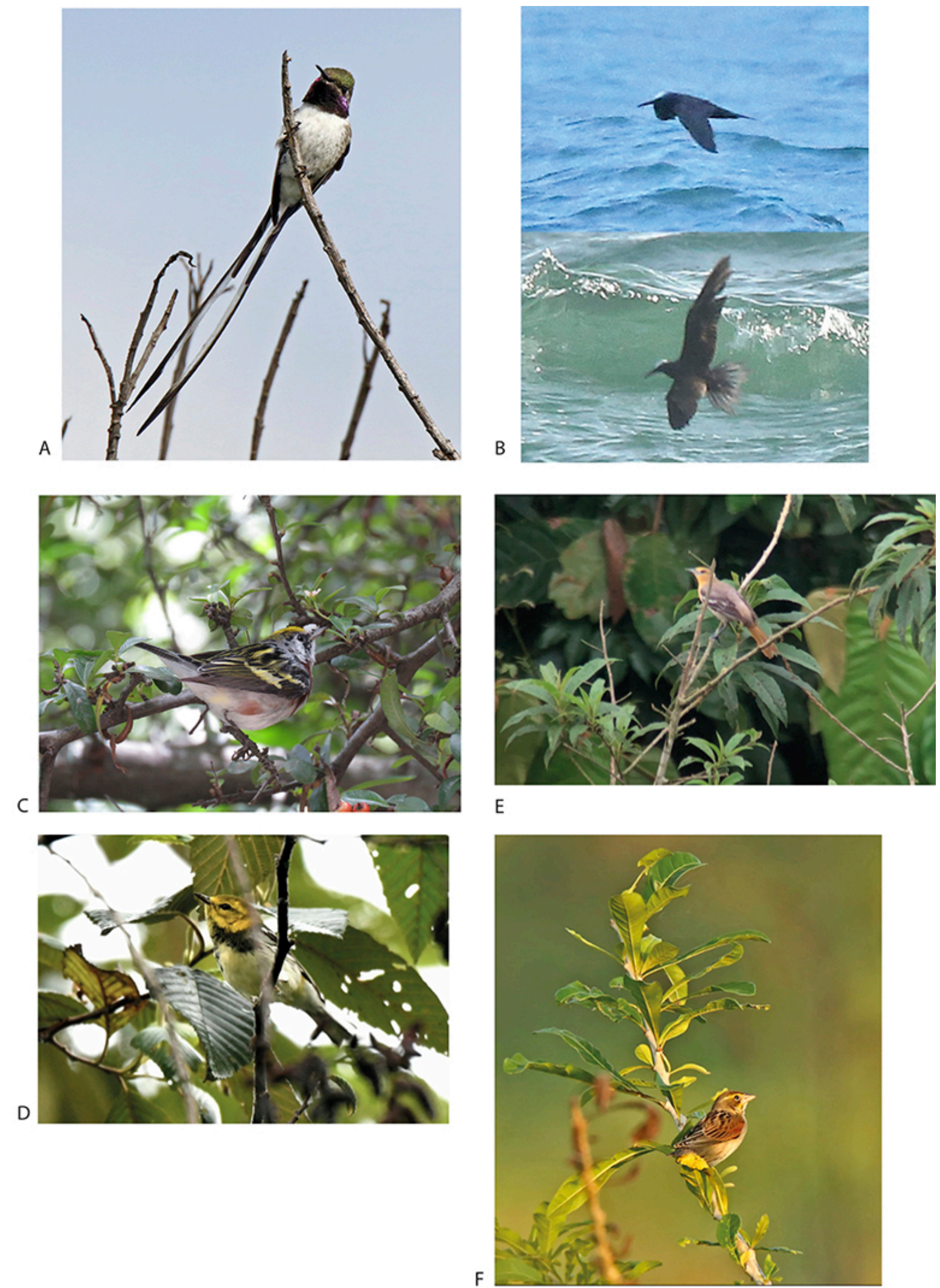

Figure 2: First documented records of species previously considered hypothetical/undocumented in mainland Ecuador. a) Thaumastura cora, Jimbura, Loja province (R. Ahlman; ML 104924311); b) Anous minutus, La Chocolatera, Santa Elena province (R. Ahlman; ML 20122651); c) Setophaga pensylvanica, Jardín Botánico de Quito, Pichincha province (E. Ocaña); d) Setophaga virens, Mindo, Pichincha province (M. Bonet; ML 146581841); e) Icterus galbula, Buenaventura Reserve, El Oro province (L. Seitz; ML 135003401); f) Spiza americana, Las Peñas, Esmeraldas province (R. Ahlman; ML 20370601). 


\section{*Peruvian Diving-Petrel Pelecanoides garnotii}

Guayas Province, Puerto Engabao, 14 January 2017, F. Pásara Hurtado (photo).

A single exhausted individual of this globally endangered species (BirdLife International, 2020) was rescued while swimming close to shore (Fig. 1a). It died afterwards, but the specimen was not secured and no necropsy analysis was done. This constitutes the first record for Ecuador and the northernmost record for the genus and species, $c .440 \mathrm{~km}$ north of Lobos de Tierra, the nearest coastal area where recorded in Peru, even though it has not bred there for several decades (Figueroa, 2013). The closest breeding colony lies $370 \mathrm{~km}$ further southeast of Lobos de Tierra, at Isla Corcovado (Valverde-Romero, 2006).

This Humboldt Current species likely breeds year-round in coastal areas and islands of Peru and Chile (Howell \& Zufelt, 2019; BirdLife International, 2020) and is considered to be sedentary (Onley \& Scofield, 2007). The species is not known to wander or disperse over long distances under normal climatic conditions (Carboneras et al., 2020), but it is affected by abnormal climatic situations, because it feeds mostly on small pelagic fish that are more susceptible to changes in sea surface temperature (Brooke, 2004; García-Godos \& Goya, 2006). Therefore, its dispersion northwards to the southern coast of Ecuador might have been caused by the weak coldwater event La Niña, as part of the El Niño Southern Oscillation (ENSO), that produced nutrient-rich and cooler water conditions in the eastern tropical Pacific from late 2016 to early 2017 (L'Heureux et al., 2017). With cold ocean waters being more productive, this $P$. garnotii might have travelled north in search for prey, as has been hypothesized for other marine organisms (Álava \& Carvajal, 2005; Páez-Rosas et al., 2018). Nonetheless, we cannot fully rule out the possibility of a boat-assisted arrival to the Ecuadorian coast because diving-petrels often land on ships when attracted by lights (Howell \& Zufelt, 2019).

\section{Wood Stork Mycteria americana}

Pichincha Province, Reserva Mashpi Shungo, 9 November 2015, A. Solano-Ugalde.

Napo Province, Borja bypass, secondary road, 28 March 2019, M. Sánchez-Nivicela, M. and L. Ramsey, L. Pérez (photo).

One individual was seen flying over a river edge near Mashpi Shungo, and another pair was photographed at the Borja bypass (Fig. 4k). Both records are outside this species' regular distribution range (Freile \& Restall, 2018), but the species tends to wander widely, including trans-Andean passage (Ridgely \& Greenfield, 2020).

\section{Tricolored Heron Egretta tricolor}

Galápagos Province, Punta Cormorán, Floreana, May 2018, J. and E. Morton (photo).

One individual of undetermined age and sex was observed and photographed (Fig. 3b) at Flamingo Lagoon, Punta Cormorán, as it flew and landed along the shoreline. This is the first documented record for Galápagos. Only one previous sighting was reported by Swash \& Still (2000) without supporting evidence or further data (Wiedenfeld, 2006).

\section{Reddish Egret Egretta rufescens}

Santa Elena Province, Ecuasal Pacoa, 10 June 2019, B. Haase (photo).

One adult of undetermined sex was observed in artificial salt-evaporating ponds (Fig. 5k). Presumably, the same individual remained in the area for 8 months, with the most recent report coming from February 2020 (eBird, 2020). Two previous records exist in Ecuador, one individual seen in Río Napo in July 2009 and one observed at Pacoa from November 2013 through September 2014 (Freile et al., 2013; Nilsson et al., 2014), with the latter apparently remaining at Pacoa until October 2015 (Haase, 2019). Dates of the three records, and this individual's extended residence at Pacoa, suggest a tendency of this species to establish itself temporarily at new localities after post-breeding dispersal, and to complete pre-basic molt before migrating back to its breeding grounds. It breeds in southern North America, the Caribbean, and the northern coast of South America (Koczur et al., 2020). 


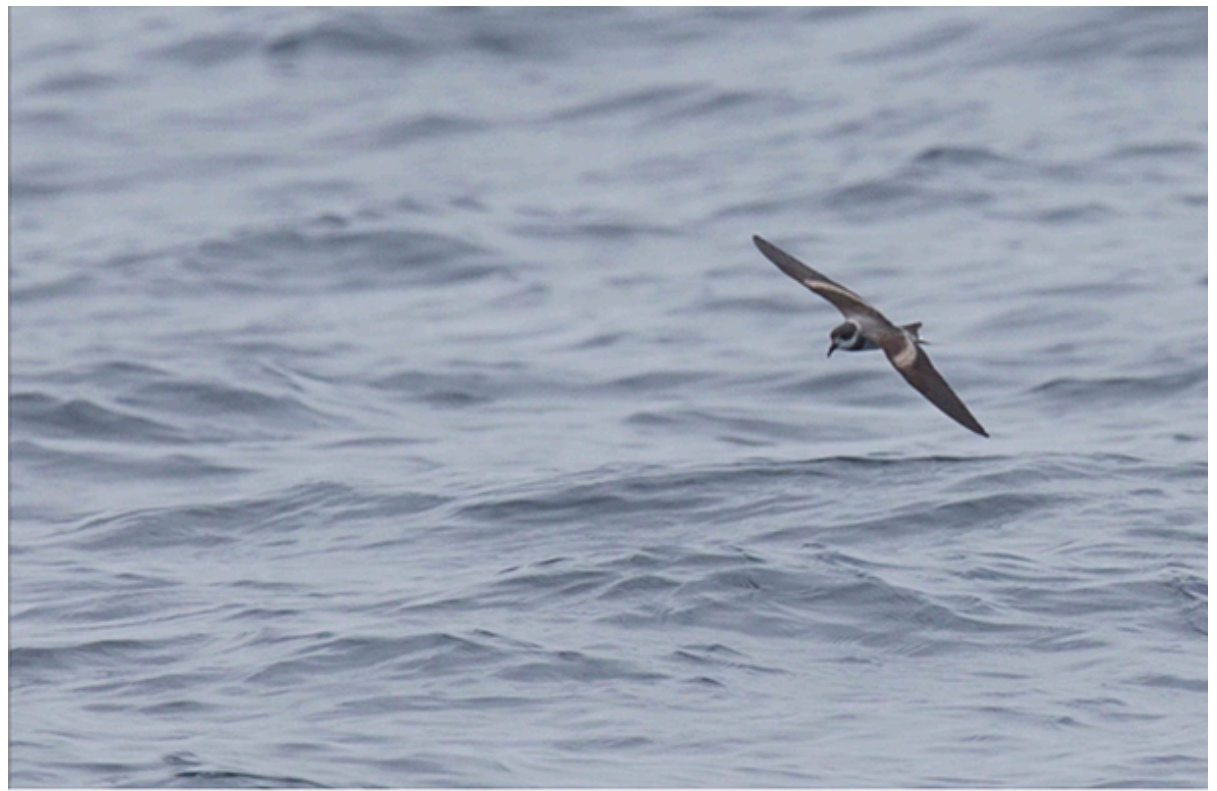

A

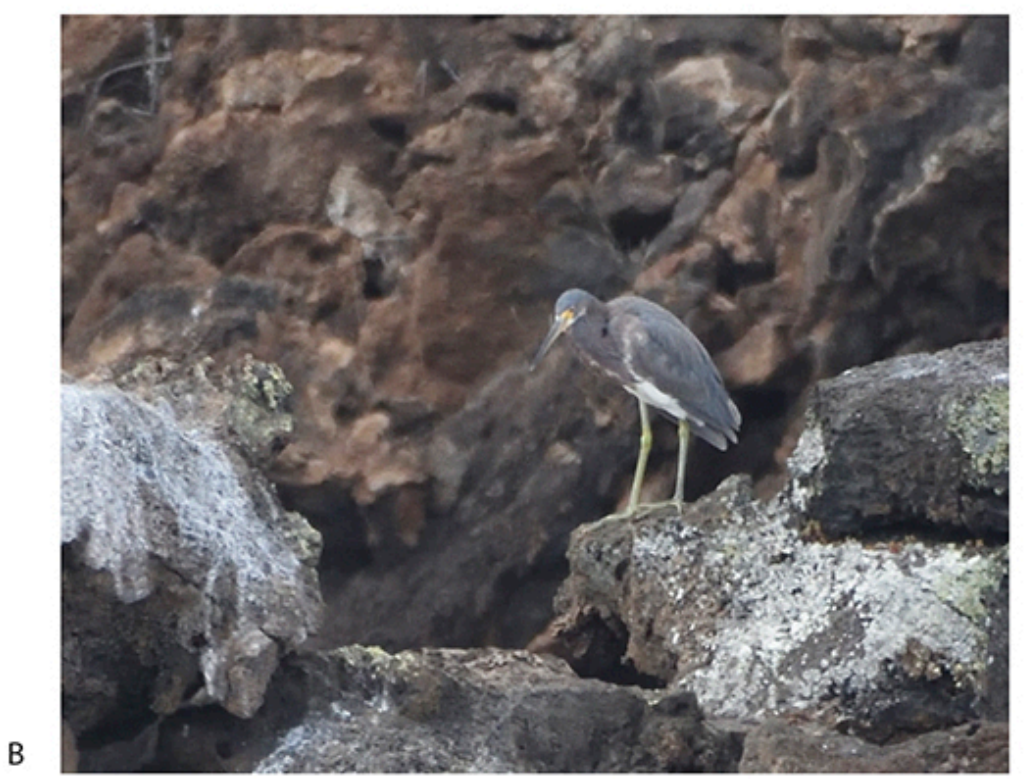

Figure 3: First documented records of species previously considered as hypothetical/undocumented in Galápagos, Ecuador. a) Oceanodroma hornbyi, off southern Isla Floreana, Galápagos province (R. Tizard; ML 86890521); b) Egretta tricolor, Punta Cormorant, Isla Floreana, Galápagos province (J. Morton).

\section{Glossy Ibis Plegadis falcinellus}

Imbabura Province, Laguna Yaguarcocha, 11 February 2015, D. Arias, L. Calapi (photo).

Sucumbíos Province, Puerto El Carmen de Putumayo, 17 January 2017, R. Ahlman, D. Jumbo (photo).

One individual was observed near a communal roost of Cattle Egrets Bubulcus ibis at Laguna Yaguarcocha (Arias-Cruzatty, 2015; Fig. 41). Another individual was observed along the banks of a pond in degraded habitat near Puerto El Carmen de Putumayo (Fig. 4m). The Yaguarcocha record is the first in the Andes of Ecuador, while the Puerto El Carmen record is only the second known to us from the Amazonian lowlands of Ecuador (Freile \& Restall, 2018). Number of records and abundance of this species in Ecuador have increased notably in recent years, from few localities and low numbers in the late 1990s and early 2000s (López-Lanús \& Gastezzi, 2000; Ridgely \& Greenfield, 2001) to several localities and increasing counts in the 2010s (Santander et al., 2013; Nilsson et al., 2014; Freile \& Restall, 2018). 


\section{Puna Ibis Plegadis ridgwayi}

Pichincha Province, Laguna de Limpiopungo, 21 August 2018, N. G. Monteros (photo).

Pichincha Province, Laguna de Limpiopungo, 22 August 2018, F. Melo (photo).

Both records refer to the same individual (Fig. 51), observed at Limpiopungo from 21 August until at least 21 September 2018 (Salazar, 2018). There is one previous record at the same locality of a single individual observed on 3-15 January 2015 (Freile et al., 2019).

\section{Pearl Kite Gampsonyx swainsonii}

Zamora Chinchipe Province, Paquisha, 18 May 2018, F. Castillo (photo).

One adult was first observed at Paquisha on 18-29 May 2018 (Fig. 4n) and the species continued to be observed regularly in and around the town through at least January 2020 (eBird, 2020). This is one of the southernmost records in Amazonian Ecuador, where the species is primarily confined to the northern lowlands (Freile \& Restall, 2018). However, it is likely colonizing new areas towards the Andean foothills and southern Amazonian Ecuador following deforestation (Ridgely \& Greenfield, 2020).

\section{Snail Kite Rostrhamus sociabilis}

Pichincha Province, Reserva Mashpi Shungo, 8 January 2018, D. Chalá, A. Solano-Ugalde (photo).

Pichincha Province, Laguna de Limpiopungo, 15 February 2018, Z. Armas (photo).

The Mashpi record involves a juvenile found in weakened condition, which later died (Fig. 4o), whereas the Limpiopungo record also involves a juvenile, but in good condition (Fig. 4p). The Limpiopungo bird was persistently being mobbed by a resident Andean Lapwing Vanellus resplendens and an Andean Gull Chroicocephalus serranus. This species was considered Vulnerable in Ecuador by Granizo et al. (2002), but is likely increasing in numbers at present, especially in western Ecuador, and spreading northwards and into the Andean foothills; as a result, it has been removed from the country's red list (Freile et al., 2019b). There is a single previous highland record of an adult found dead, curiously also at Limpiopungo (de Vries, 1980).

\section{Gray-bellied Hawk Accipiter poliogaster}

Orellana Province, Shiripuno, 20 May 2012, R. Gelis (photo).

One adult was encountered inside primary forest, where it was depredating an unknown bird (Gelis, 2012). Apparently, this rare hawk has a wide distribution across the entire Amazon Basin, but it is poorly known and seldom recorded in Ecuador (Freile \& Restall, 2018). There are a few additional records available in eBird, including one juvenile at Sumaco at a higher elevation than expected (Espinosa, 2015), an adult near Paquisha (Castillo, 2020), and another juvenile at Nuevo Paraíso Road, Zamora Chinchipe province, which is the southernmost record (Tizard, 2017).

\section{Swainson's Hawk Buteo swainsonii}

Manabí Province, Manantiales, 29 May 2018, G. Donoso (photo).

One subadult of undetermined sex was found in weakened condition at a farm (Fig. 5m), but apparently escaped after being photographed (G. Donoso, in litt., May 2018). There are few records of this boreal transient hawk in western Ecuador (Freile \& Restall, 2018). The May date indicates a delayed migrant.

\section{Koepcke's Screech-Owl Megascops koepckeae}

Loja Province, campus of Universidad Técnica Particular de Loja (UTPL), urban Loja, February-May 2018, L. Ordóñez, A. Orihuela, A. Armijos, J. Freile (photos, audio-recordings).

A small population was unexpectedly discovered on the UTPL campus, within the city of Loja (Fig. 5n), and a few additional territories have subsequently been located in the Loja valley since then (Ordóñez-Delgado \& Freile, 2019). This former Peruvian endemic owl has been recorded from Ayabaca province, $c .90 \mathrm{~km}$ south of Loja, so it might occur in other dry Andean valleys in the intervening area (Ordóñez-Delgado \& Freile, 2019). 
A

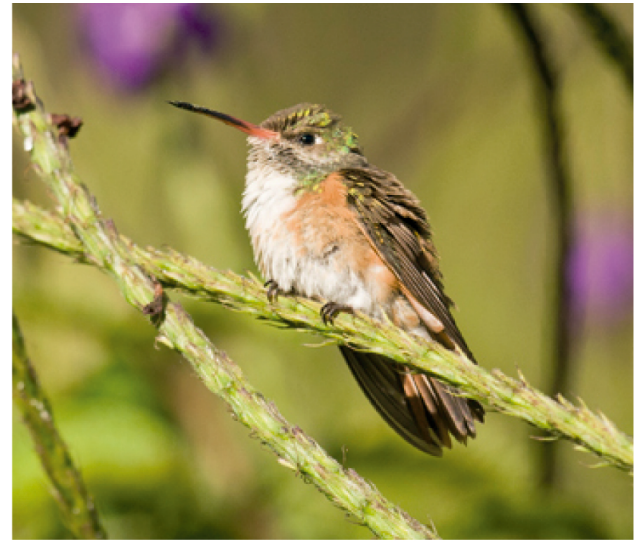

B

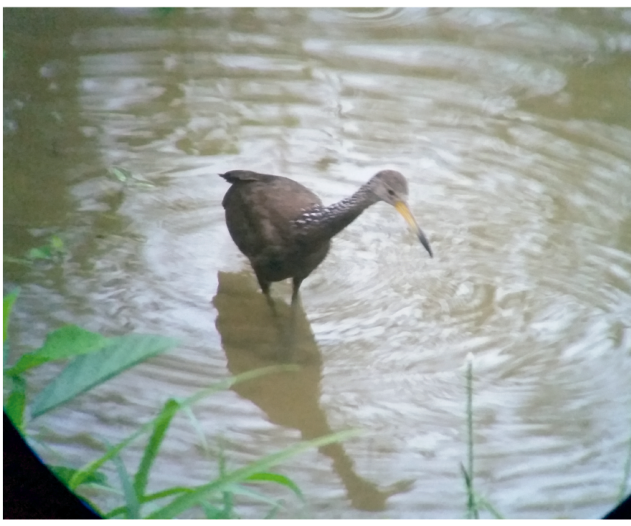

C

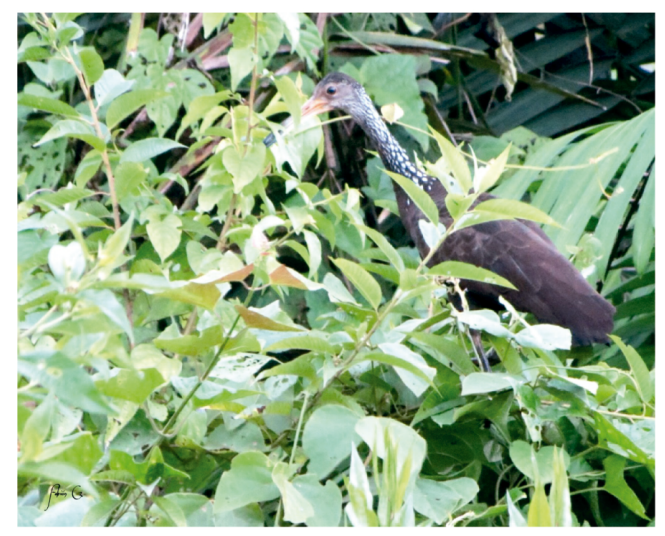

D

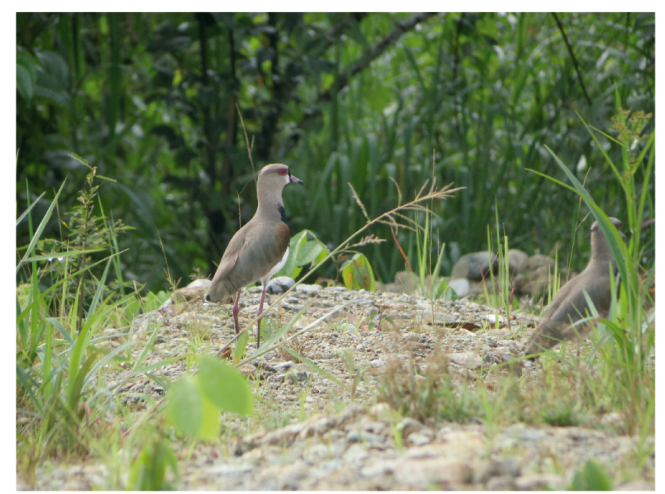

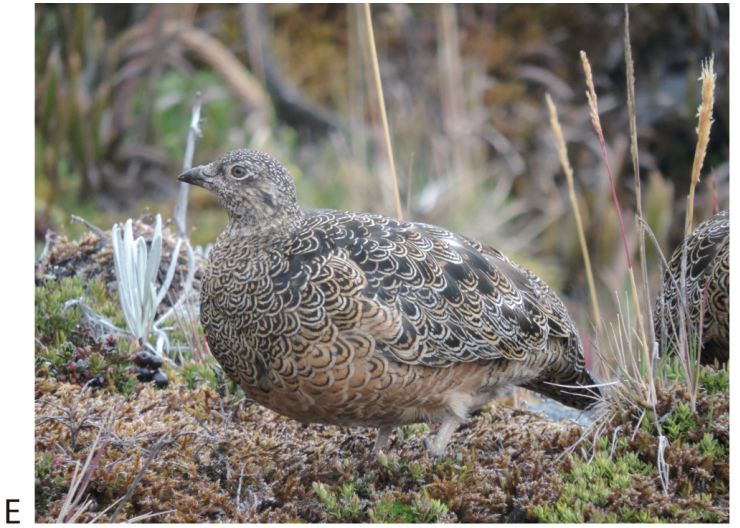
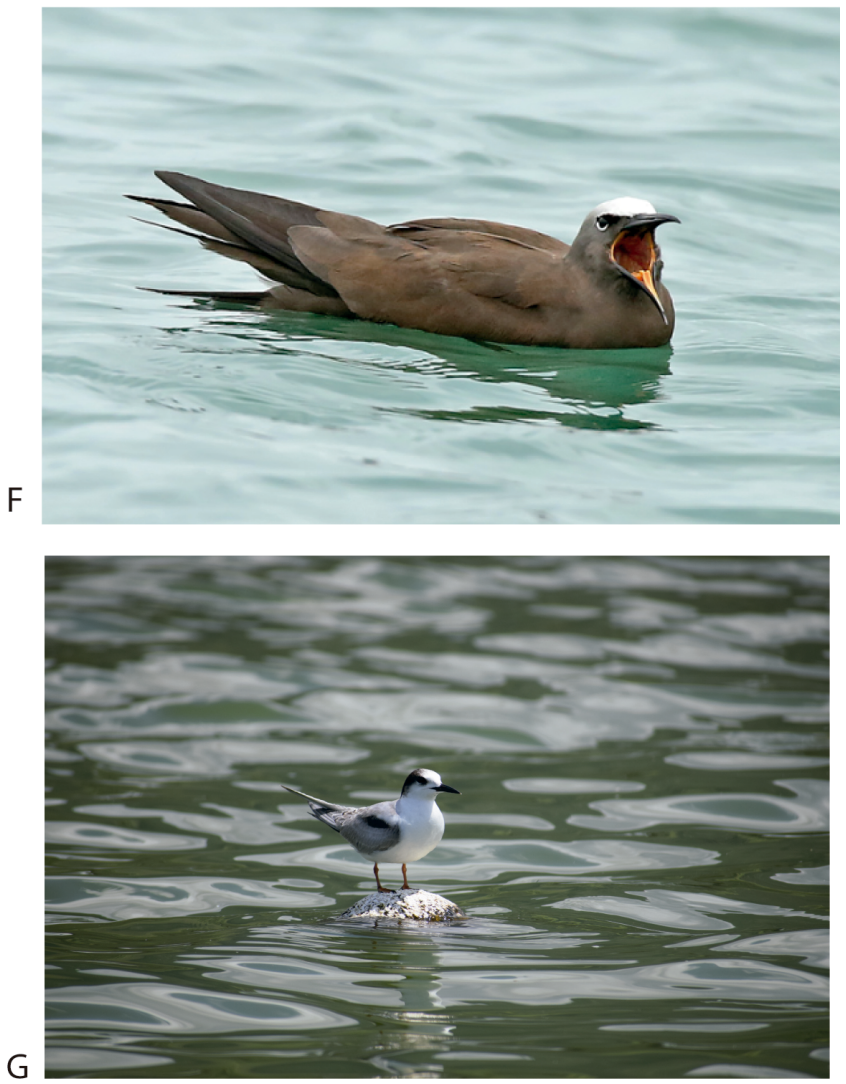

$\mathrm{G}$

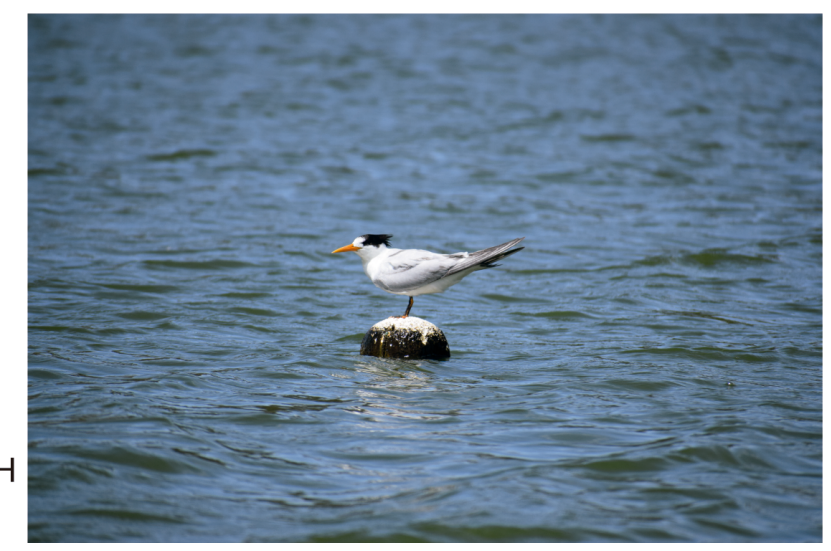

Figure 4: Major range extensions and extralimital records of birds in Ecuador. a) Amazilia amazilia, Copalinga Lodge, Zamora-Chinchipe province (R. Goodell); b) Aramus guarauna, Mashpi, Pichincha province (A. Solano-Ugalde); c) Aramus guarauna, Paquisha, Zamora-Chinchipe province (F. Castillo); d) Vanellus chilensis, Paquisha, Zamora-Chinchipe province (F. Castillo); e) Attagis gayi, south side Volcán Chiles, Carchi province (E. Taimal); f) Anous stolidus, off Punta Galera, Esmeraldas province (R. Ahlman; ML 204999951); g) Sterna hirundo, Yaguarcocha, Imbabura province (E. Obando); h) Thalasseus elegans, Yaguarcocha, Imbabura province (E. Obando)... 

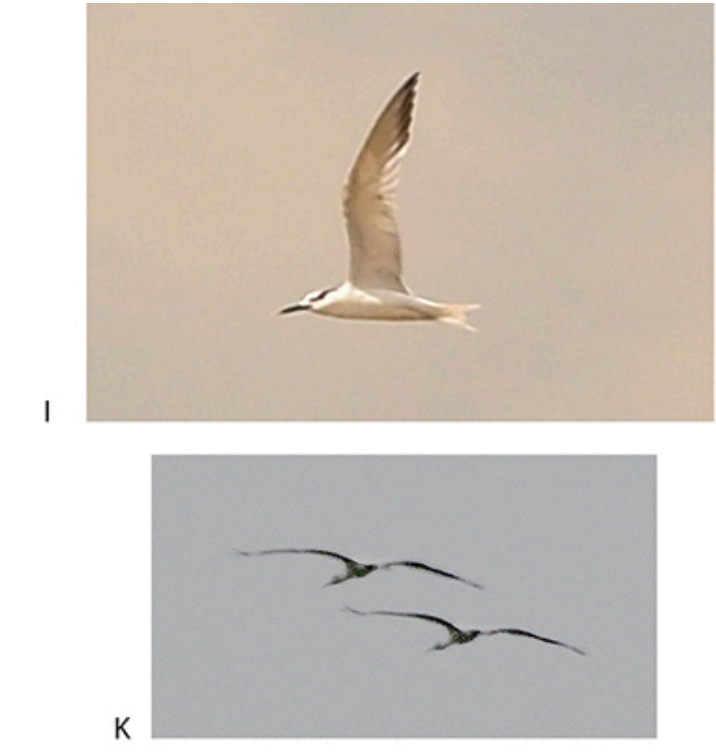

L

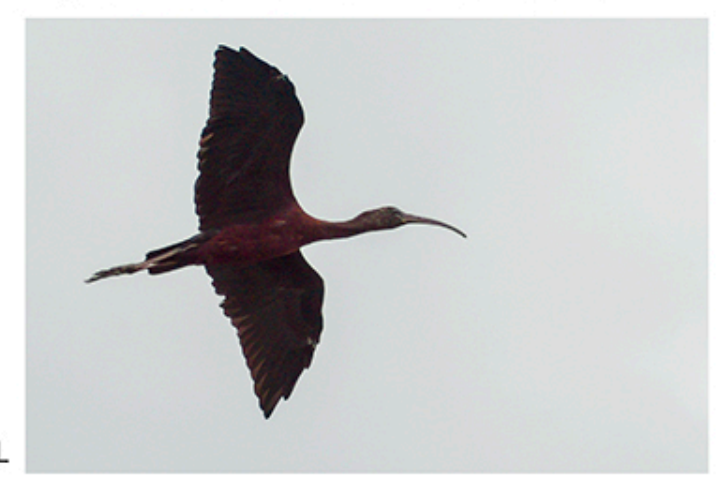

M
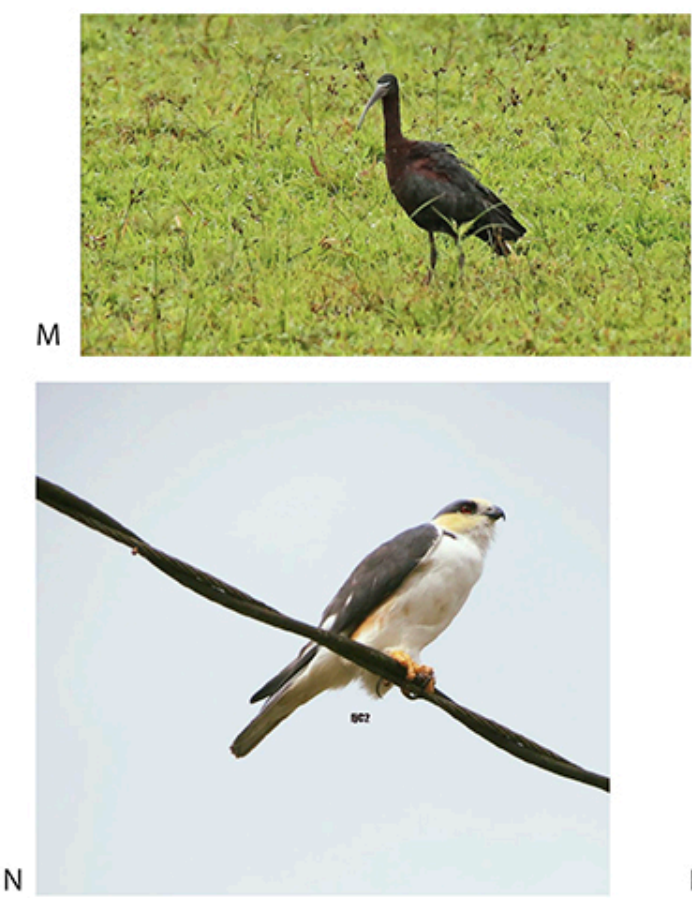
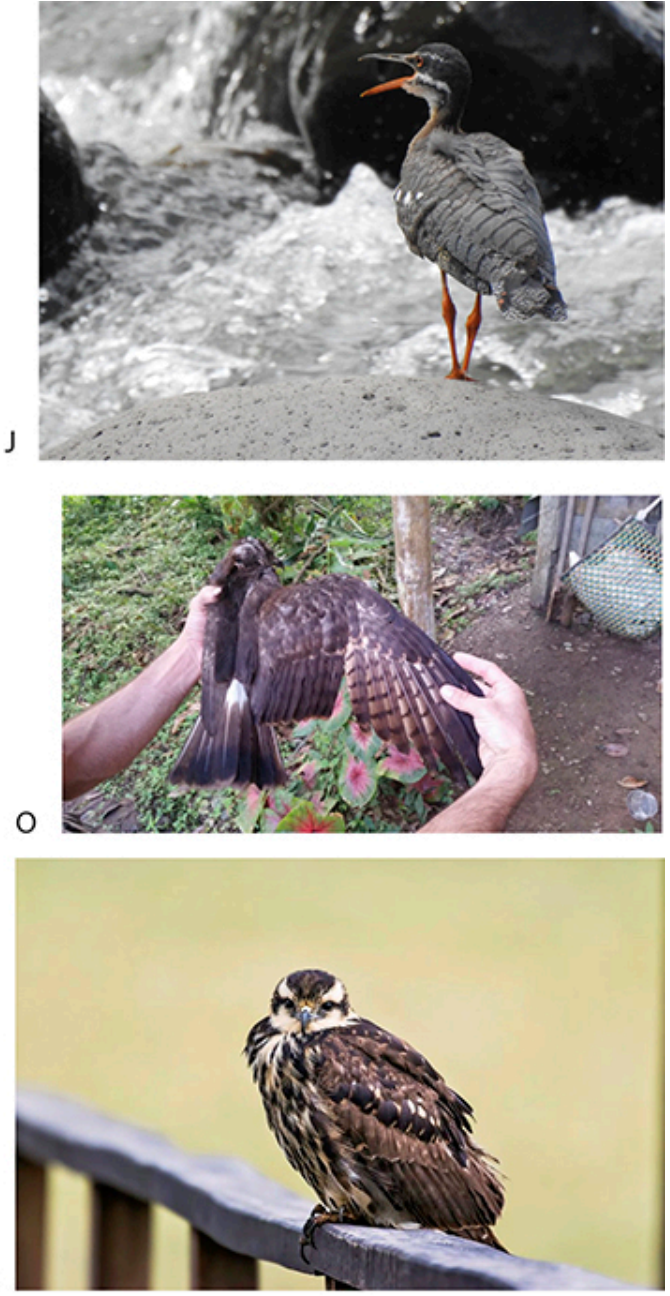

Q
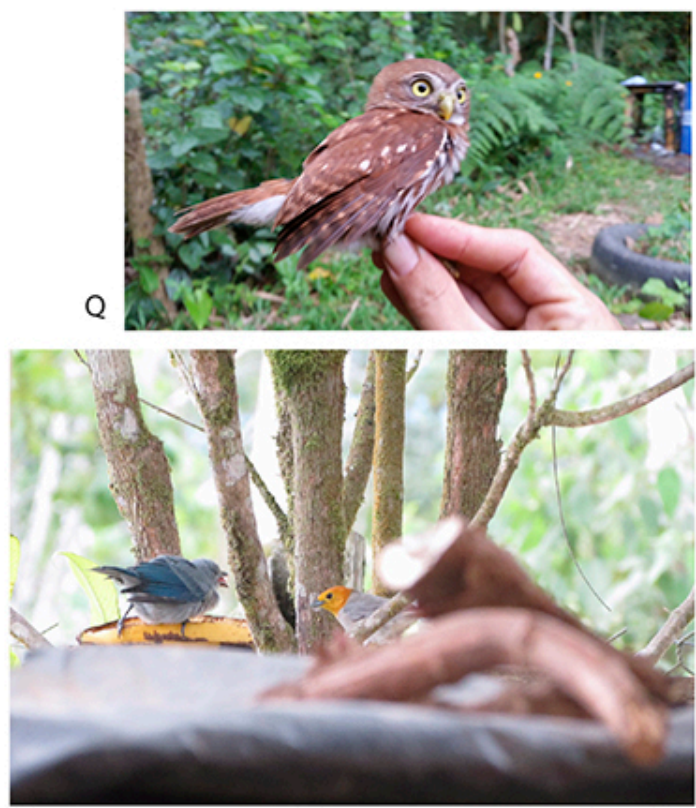

Figure 4: Major range extensions and extralimital records of birds in Ecuador. ...i) Thalasseus sandvicensis, 10-15 km down river from Coca, Orellana province (B. Nooner); j) Sunbittern Eurypyga helias meridionalis (C. A. Vásquez); k) Mycteria americana, Borja bypass, Napo province (L. Ramsey); 1) Plegadis falcinellus, Yaguarcocha, Imbabura province (D. Arias-Cruzatty); m) Plegadis falcinellus, Puerto El Carmen de Putumayo, Sucumbíos province (R. Ahlman; ML 205005521); n) Gampsonyx swainsonii, Paquisha, Zamora-Chinchipe province (F. Castillo); o) Rostrhamus sociabilis, Mashpi, Pichincha province (A. Solano-Ugalde); p) Rostrhamus sociabilis, Limpiopungo, Pichincha province (Z. Armas); q) Glaucidium peruanum, Mashpi, Pichincha province (A. Solano-Ugalde); r) Thlypopsis sordida, Paquisha, ZamoraChinchipe province (F. Castillo). 


\section{Pacific Pygmy-Owl Glaucidium peruanum}

Pichincha Province, Pachijal, 11 January 2018, F. Bolaños, A. Solano-Ugalde (photo).

One individual was rescued after crashing against a window; it recovered and was released the following day at Mashpi Shungo (Fig. 4q). Pachijal and Mashpi are outside the species' regular distributional range, but there are records from nearby areas in Pichincha province (Río Silanche, Puerto Quito), and further north in Cristóbal Colón, Esmeraldas province (eBird, 2020). Increasing deforestation, expansion of the agricultural frontier, and local climate changes (i.e., decreasing humidity) might be the drivers of its range expansion.

\section{White-throated Kingbird Tyrannus albogularis}

Orellana Province, Nuevo Rocafuerte, 7 May 2018, R. Ahlman (photo).

Two separate individuals were seen nearby Nuevo Rocafuerte and readily identified as different from Tropical Kingbird Tyrannus melancholicus by the clear-cut white throat, clean yellow below, lack of olive wash on the breast, pale gray head, pronounced dark mask, and clear-cut green back (Fig. 5o). A short trill call of this individual was recorded (Ahlman, 2018c). There are a few additional sightings in the same general area and further west along the Río Napo (eBird, 2020). This record along with associated published evidence (Ahlman, 2018b), represent the first documentation for the species in Ecuador (Freile et al., 2020).

\section{Bobolink Dolichonyx oryzivorus}

Esmeraldas Province, Punta Galera, 11 October 2015, R. Ahlman (photo).

A flock of four individuals was encountered in dry scrub near the coast (Fig. 5q). There are few records of vagrants in Ecuador, including records from the Galápagos Islands (Wiedenfeld, 2006; Freile \& Restall, 2018; eBird, 2020). The species occurs as transient in Ecuador, with records limited to October-November and AprilMay (Freile \& Restall, 2018). Paucity of records might be explained by short transit visits that make it pass overlooked (Ridgely \& Greenfield, 2001).

\section{Yellow-backed Oriole Icterus chrysater}

Carchi Province, El Carrizal, near Tulcán, 30 March 2019, G. Lucero (photos).

One pair was found near Tulcán in a rural area characterized by cultivated land and remnant Eucalyptus globulus woodland patches (Fig. 5r). They were subsequently seen for two consecutive weeks. The pair often remained high in the Eucalyptus trees, but sometimes descended to nearby shrubs. They were found again in June 2019 (eBird, 2020). This is only the second Ecuadorian record of this species, which actually ranges to extreme southern Colombia (Ayerbe-Quiñones, 2018).

\section{Baltimore Oriole Icterus galbula}

El Oro Province, Buenaventura Reserve, 29 December 2018, L. Seitz (photo).

A single individual, presumably an immature male, was briefly observed and photographed (Fig. 2e). As admitted by the observer, it is not easy to separate a pure Icterus galbula from a hybrid I. galbula x Bullock's Oriole I. bullockii (Seitz, 2018). Some details that could differentiate these two species and a range of hybrid plumages are not appreciable in the photograph (belly color and pattern, molt wear in wing feathers). Thus, it is not possible to segregate with $100 \%$ certainty between I. galbula and I. bullockii (A. Jaramillo, in litt., March 2020; see Jaramillo \& Burke, 1999). Yet, CERO accepts the record as pertaining to I. galbula based on known wintering ranges of the two species. This is the fifth record of I. galbula in Ecuador (Freile \& Restall, 2018). There is a recent photographic record of a non-breeding male in Puembo Birding Garden, Pichincha province (Mac, 2020).

\section{Bay-breasted Warbler Setophaga castanea}

Pichincha Province, Mindo, road to Mariposario, 13 March 2019, D. Jumbo (photo).

A male molting into breeding plumage was observed in a second-growth patch near Mindo, foraging in Inga and Alnus trees (Fig. 5p). It moved in the same flock as a Black-throated Green Warbler S. virens (see below). 
There are few previous records for northern Ecuador (Freile \& Restall, 2018; eBird, 2020). There is a report from the same location in February 2020 (Jumbo, 2020).

\section{Chestnut-sided Warbler Setophaga pensylvanica}

Pichincha Province, Jardín Botánico de Quito, 18 February 2019, J. Freile.

A single female was first recorded on 18 December 2018 by A. Morales \& G. Nazati. The first photos taken of this individual show a full non-breeding plumage (see eBird, 2020). It remained in the same area until at least 16 May 2019, allowing for photographic documentation of its molt progression into breeding plumage. By 9 February it had begun its molt and by 14 March it was already in full breeding plumage (Fig. 2c). There are few, scattered records in northern Ecuador (Freile \& Restall, 2018; eBird, 2020), mostly on April-May, and this is the first documented evidence to be formally published. There is an earlier photographic record by D. M. Brinkhuizen of a first-year male from Mindo (Brinkhuizen, 2014).

\section{Black-throated Green Warbler Setophaga virens}

Pichincha Province, Mindo, road to Mariposario, 10 March 2019, E. Capella, M. Bonet (photo).

One male molting into breeding plumage was first found on 10 March 2019 in the canopy of second growth, mostly accompanying mixed-species flocks (Bonet, 2019; Fig. 2d). It was last found on 3 April 2019 (eBird, 2020). There are very few and scattered records in Ecuador, this one being the first documented (Freile \& Restall, 2018).

\section{*Western Tanager Piranga ludoviciana}

Pichincha Province, Reserva Otongachi, 2 May 2019, A. G. Simbaña Jaramillo (photo).

One second-year male molting into breeding plumage was photographed while visiting a fruit feeder (Fig. 1b). It is not known if this individual remained in the area because observations were limited to a single day. This is the first record for Ecuador and South America (Remsen et al., 2020) and comes on an unexpected date. The species winters in Central America, south to westernmost Panamá and adjacent Costa Rica, from where it departs by late March through April (Hudon, 2020). Previous records outside its typical wintering range or breeding grounds during the boreal spring are confined to northern United States and central-east Canada (Hudon, 2020). The southernmost record comes from Finca Velásquez, Veraguas, Panamá (Groenendijk, 2018), $850 \mathrm{~km}$ north-northwest of Reserva Otongachi, whereas the closest record to South America comes from the island of Bonaire (Wells \& Childs-Wells, 2002).

The mechanism by which this individual arrived to northwest Ecuador cannot be determined with certainty, but two possibilities stand out. First, it could represent an overshooting migrant, which might have passed its normal winter grounds during fall migration and overwintered in Ecuador while remaining undetected. However, considering the late date and the tendency of the species to vacate southern wintering areas in March and April (Hudon, 2020), it seems more plausible that this individual engaged in reverse migration as a result of misorientation. It has been proposed that a small number of individuals in migratory species depart their wintering grounds in a $180^{\circ}$ reverse direction, just as some individuals seem to do when departing their breeding grounds (Howell et al., 2014). From many points in the core wintering range of $P$. ludoviciana along the Pacific slope of Central America, the area in northwest Ecuador where this individual was found lies on a straight $180^{\circ}$ directly opposite the species' breeding areas in North America.

\section{Dickcissel Spiza americana}

Esmeraldas Province, Las Peñas, 12 October 2015, R. Ahlman (photo).

A single adult was located in an open field with shrubby vegetation (Fig. 2f). There is only one previous record for Ecuador, an undocumented observation from Jatun Sacha, Napo province (Clay, 1999). The Las Peñas record provides the first documentation of the species for Ecuador (see eBird, 2020). There is one additional, recent record from the same area (Rowlett, 2019). 


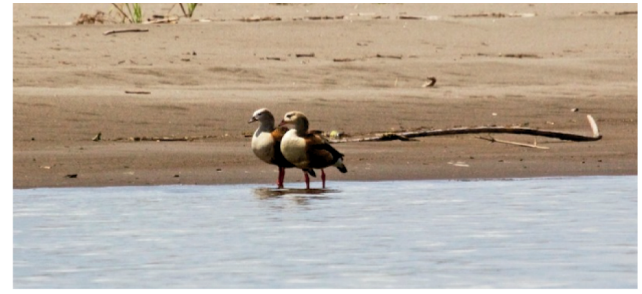

A

C

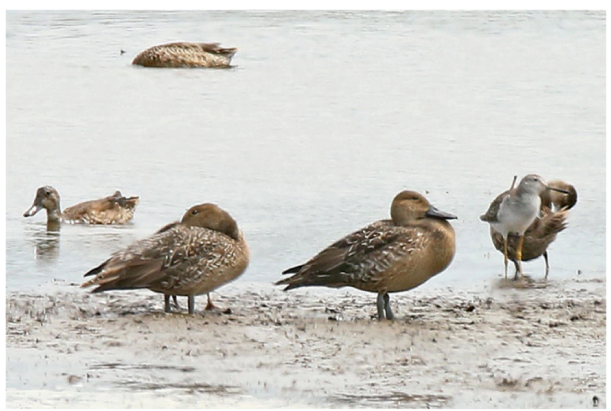

$\mathrm{E}$

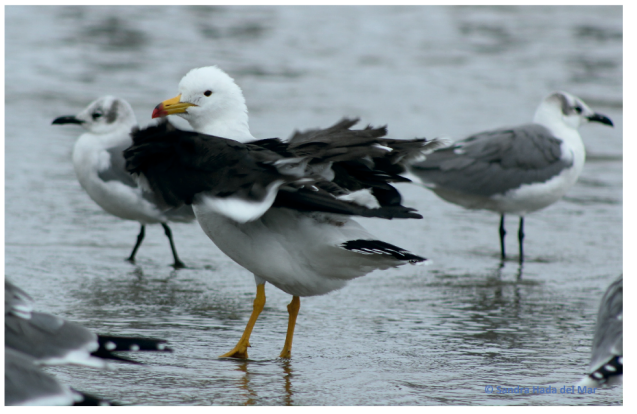

G

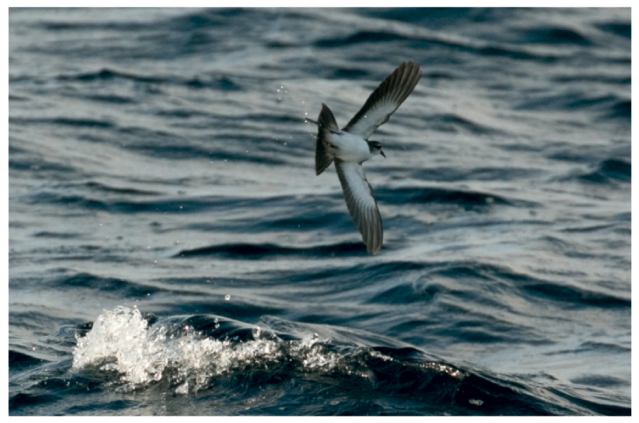

।

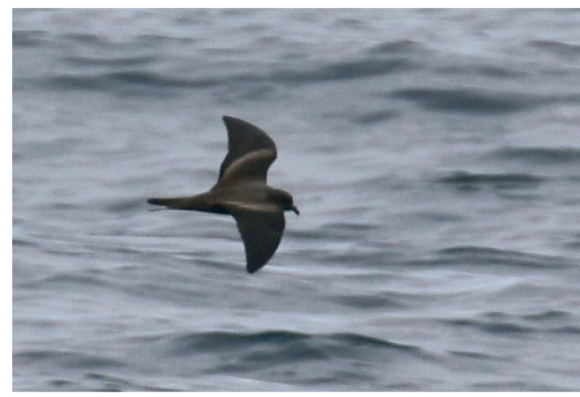

B

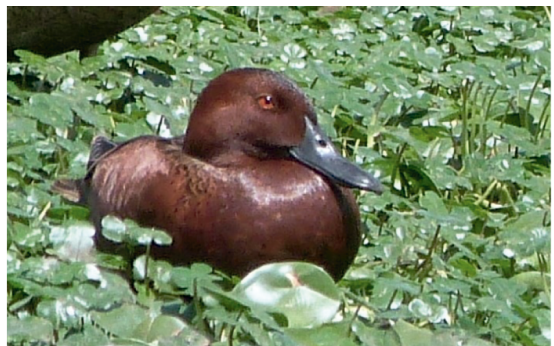

D

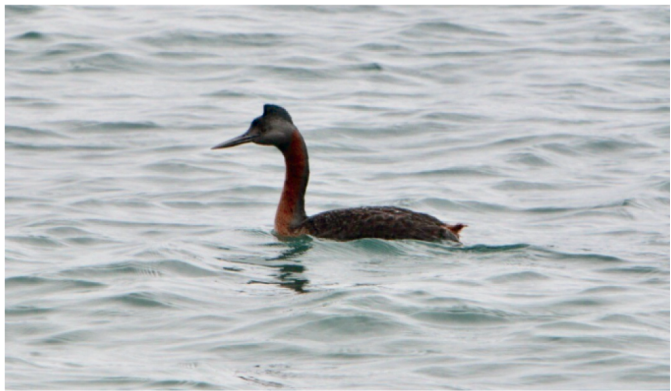

$\mathrm{F}$
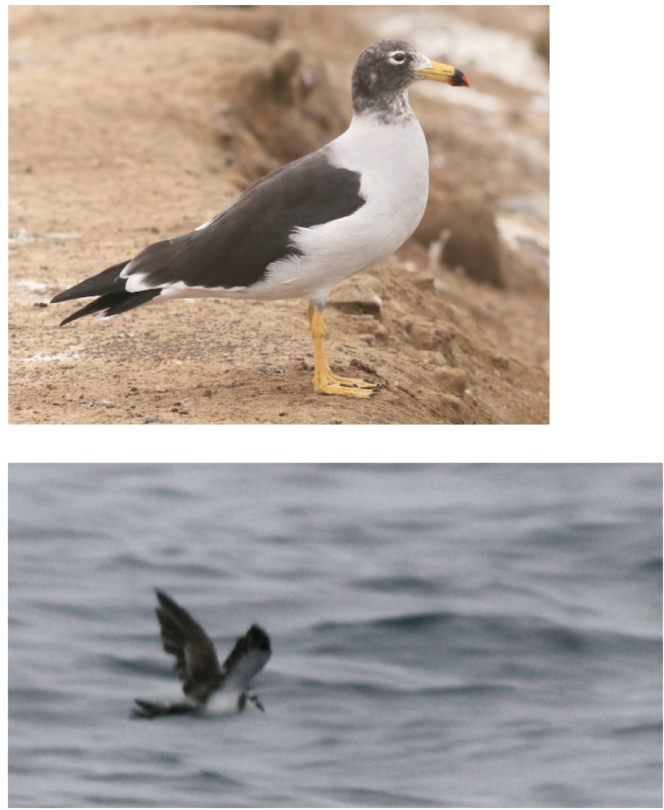

$\mathrm{H}$

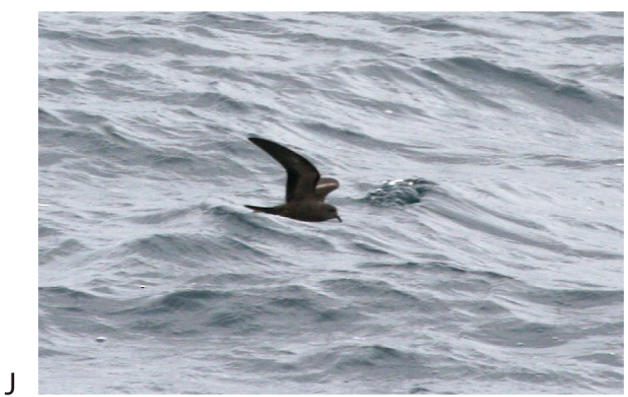

Figure 5: Rare birds recorded in Ecuador. a) Oressochen jubatus, clay licks in south bank of Napo River near Yasuni National Park control, Orellana province (P. Petrus; ML 65893401); b) Spatula cyanoptera, Lago San Pablo, Imbabura province (C. Vogt; ML 44409931); c) Anas acuta, Las Peñas, Esmeraldas province (R. Ahlman; ML 41959991); d) Podiceps major, Isla de la Plata, Manabí province (B. Wilcox; ML 78530561); e) Larus belcheri, Puerto López, Manabí province (S. M. Plúa); f) Larus belcheri, Mar Bravo, Santa Elena province (P. Bourdin; ML 105439221); g) Pelagodroma marina, near Isla Española, Galápagos province (A. Jaramillo; ML 105290011); h) Pelagodroma marina, near Isla San Cristóbal, Galápagos province (A. Bruun Kristensen); i) Oceanodroma markhami, near Isla San Cristóbal, Galápagos province (A. Jaramillo; ML 65144431); j) Oceanodroma markhami, near Isla San Cristóbal, Galápagos province (J. Gilliam; ML 92349131)... 
K
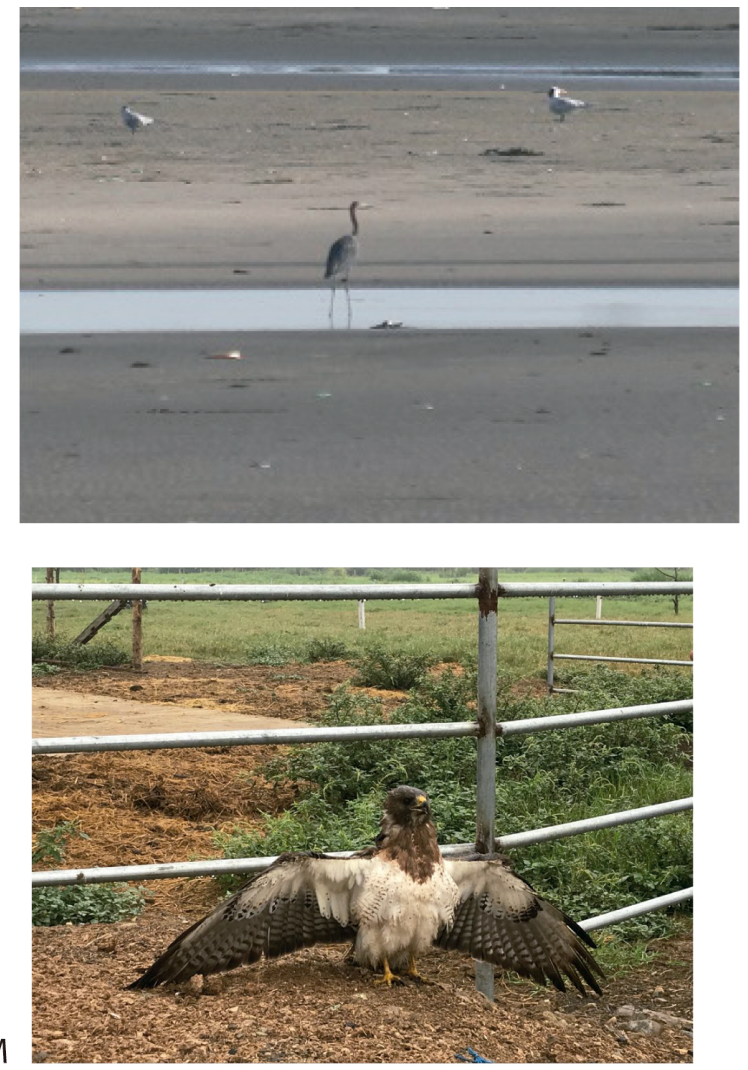

$\mathrm{O}$
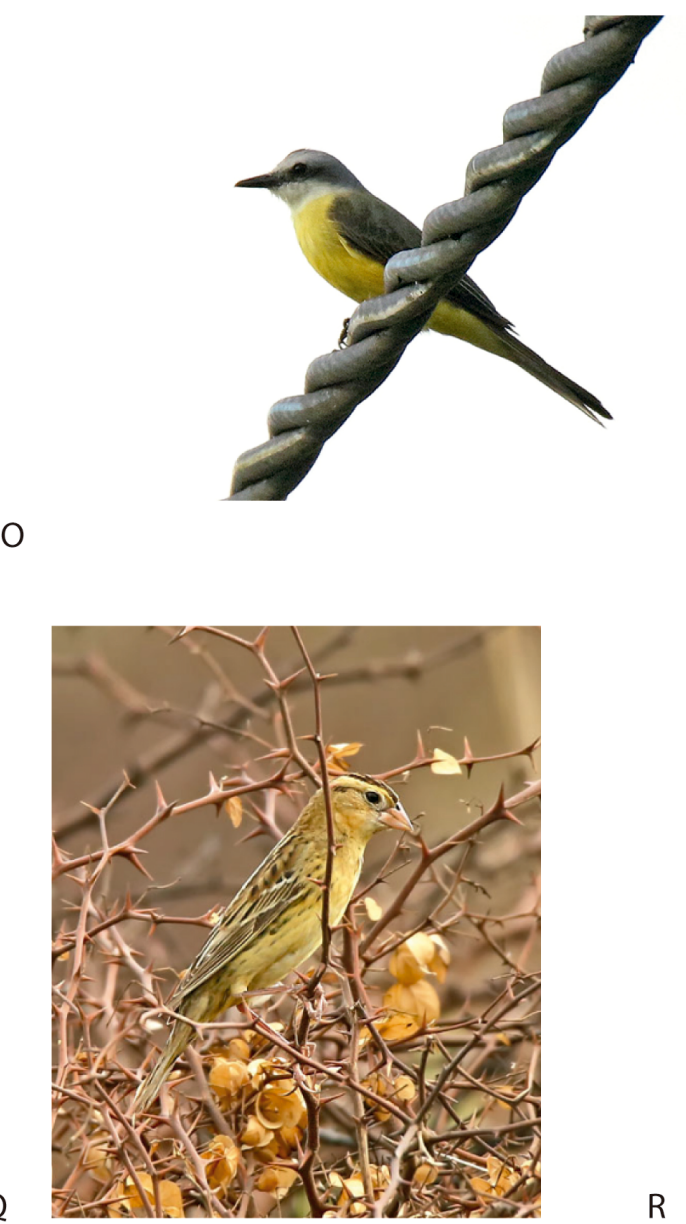

Q

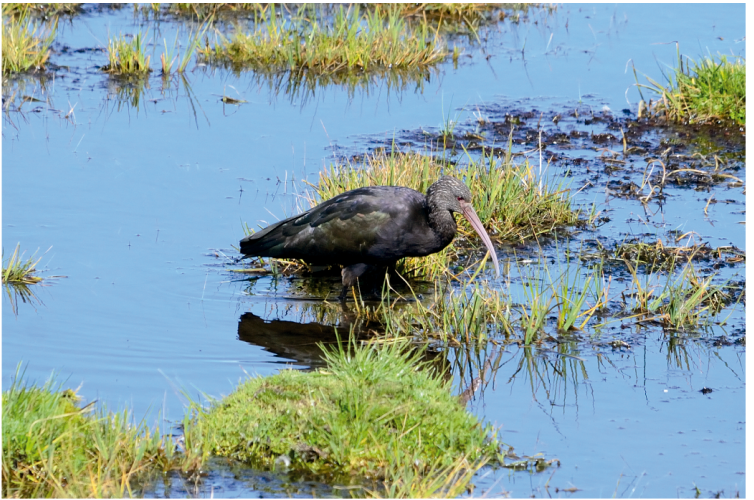

$\mathrm{L}$
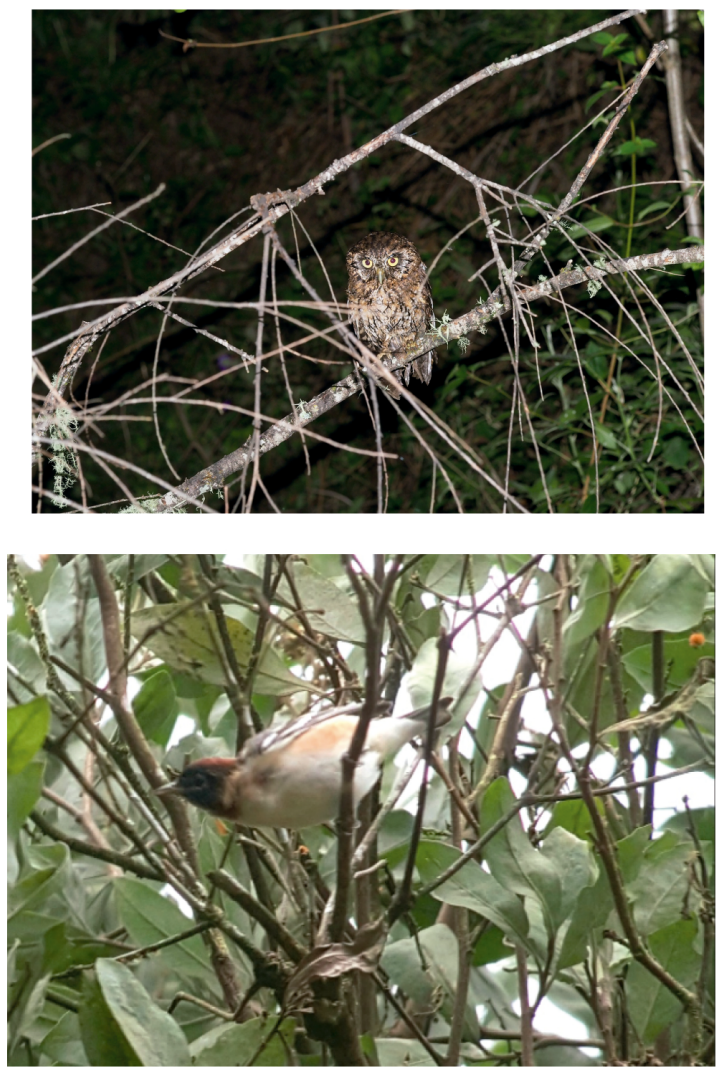

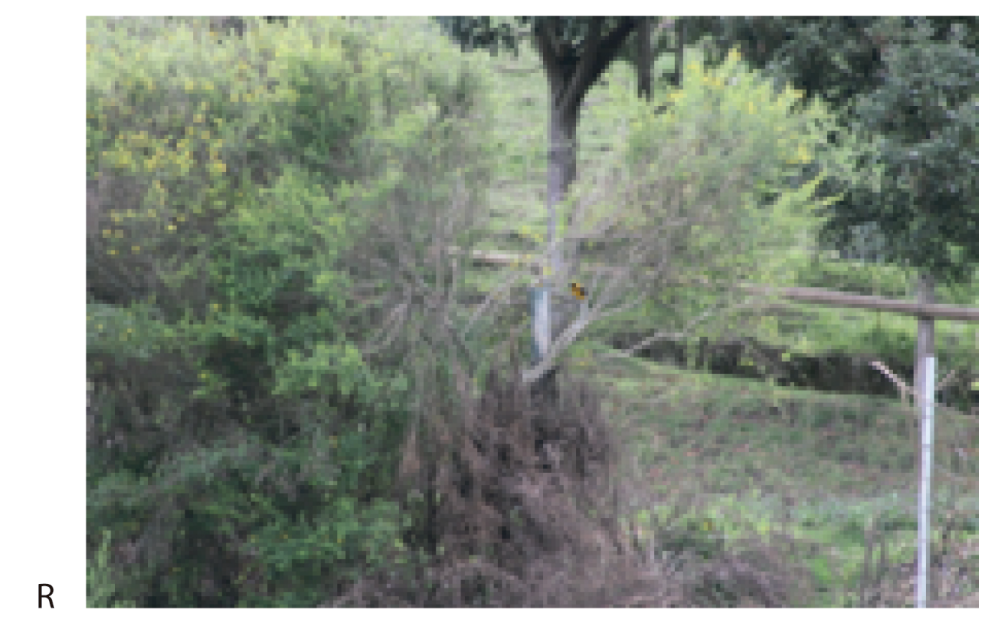

Figure 5: Rare birds recorded in Ecuador ...k) Egretta rufescens, Pacoa, Santa Elena province (B. Haase); 1) Plegadis ridgwayi, Limpiopungo, Pichincha province (N. G. Morelos); m) Buteo swainsonii, Manantiales, Manabí province (G. Donoso); n) Megascops koepckeae, Loja city, Loja province (P. Székely); o) Tyrannus albogularis, Nuevo Rocafuerte, 
Orellana province (R. Ahlman; ML 99462291); p) Setophaga castanea, Mindo, Pichincha province (D. Jumbo; ML 145236871); q) Dolichonyx oryzivorus, Punta Galera, Esmeraldas province (R. Ahlman; ML 20370761); r) Icterus chrysater, El Carrizal, Carchi province (G. Lucero).

\section{*Pearly-breasted Conebill Conirostrum margaritae}

Orellana Province, river island close to Nuevo Rocafuerte, 6 May 2018, R. Ahlman (photo).

One pair was first found in a small patch of medium-aged Cecropia on a small river island dominated by grassy vegetation (Fig. 1c; Ahlman, 2018a), where it responded strongly to playback by approaching and singing. It was observed again on 4 May 2019 by the same observer, together with J. Illanes and X. Chv (eBird, 2020). This is the first record of the species for Ecuador and one of the few records along the Río Napo-and the westernmost in the Amazon basin (Schulenberg et al., 2006).

\section{Orange-headed Tanager Thlypopsis sordida}

Zamora Chinchipe Province, Paquisha, 22 July 2017, F. Castillo (photo).

Three birds were first seen in July 2017 and remained in the area until at least the end of that year, including repeated observations at the same fruit feeder (Fig. 4r). This species is mostly confined to riparian secondary vegetation and was, until recently, mainly confined to river islands and the riparian vegetation along the shorelines of major rivers (Ridgely \& Greenfield, 2001; McMullan \& Navarrete, 2017). However, it appears to be spreading into second-growth areas away from rivers and into the Andean foothills (Krabbe, 2018; eBird, 2020), likely in response to deforestation.

\section{Other records received}

The following records, received by CERO, do not represent significant range extensions but add to our knowledge of bird distributions in Ecuador.

Gould's Jewelfront Heliodoxa aurescens. Two adults (male and female) at 24 de Mayo, Pastaza province (1618 November 2017; W. Arteaga-Chávez), mist-netted and observed in primary forest and edge at $1280 \mathrm{~m}$ a.s.l. [Mostly recorded below 1250 m, locally higher; Freile \& Restall, 2018].

Gray-capped Cuckoo Coccyzus lansbergi. One individual was observed and photographed in December 2017January 2018 at Mashpi Shungo Reserve (H. and N. Jacob, A. Solano-Ugalde). [Few records in humid lowlands of Pichincha province and neighboring areas; Freile \& Restall, 2018].

Comb Duck Sarkidiornis sylvicola. One pair was observed in June 2015 at La Tembladera (A. Solano-Ugalde, M. Sánchez-Nivicela, R. Ahlman and J. Freile) swimming in open water near floating vegetation. After first appearing in 2015, the species was again observed several times at La Tembladera in the second half of 2018 , with the highest reported count being an astonishing 300 individuals in early August (eBird, 2020). Sporadic records have continued into early 2020 (eBird, 2020). [Few localities known in Ecuador to date; trend in population numbers is not well understood, but population considered small and declining; Freile et al., $2019 \mathrm{~b}$.

Horned Screamer Anhima cornuta. Up to four individuals were seen at La Tambladera in June 2015 (A. Solano-Ugalde, M. Sánchez-Nivicela, R. Ahlman and J. Freile), where the species is regularly seen in low numbers. [Localities for this species in western Ecuador and number of individuals has increased notably in recent years (Martínez \& Gastezzi, 2014; Freile et al., 2019a)].

Gray-breasted Flycatcher Lathrotriccus griseipectus. One individual was seen, heard, and audio-recorded at Mashpi Shungo Reserve for about one month in December 2017-January 2018 in second-growth woodland and a bamboo groove. [Few records from the humid lowlands, where apparently seasonal].

Golden Grosbeak Pheucticus chrysogaster. One female was observed and photographed in a bird hide feeding with other frugivores at Reserva Los Laureles de Guasaganda, La Maná, Cotopaxi province (C. Pellet, November 2017). [Rare in subtropics and foothills of western Ecuador, where possibly expanding following deforestation]. 
Rose-breasted Grosbeak Pheucticus ludovicianus. One adult male was observed at an open area in Reserva Los Laureles de Guasaganda, La Maná, Cotopaxi province (C. Pellet, April 2018). [Considered to be a rare boreal winter resident, mostly recorded in October-March; Freile \& Restall, 2018].

White-lined Tanager Tachyphonus rufus. One individual was observed visiting a plantain feeder at Yanacocha Reserve (P. Greenfield and others, November 2018); it was mostly female-plumaged but showed some smudges of black feathers that suggested it was a young male. [Highest known record, $c .1500 \mathrm{~m}$ above its regular altitudinal range; Freile \& Restall (2018), but likely spreading due to deforestation; one pair has become regular at Yanacocha recently; first records from this locality date back to January 2018 (eBird, 2020). There are additional records from the Quito area dating back to 2015 (Ahlman, 2015a) and from the Perucho valley (Loaiza, 2020) that support the range expansion hypothesis].

\section{Rejected records}

Table 2 presents six records rejected due to insufficient information and/or erroneous identifications. CERO postponed decisions on seven additional reports because submitted information was unsatisfactory to reach a definitive conclusion. Postponed records include one species reported for the first time in Ecuador (Bronzy Jacamar Galbula leucogastra; see Carrasco, 2016), for which CERO believes further field observations are needed.

Table 2: Summary of rejected records submitted to the Committee for Ecuadorian Records in Ornithology (CERO) between November 2017-June 2019.

\begin{tabular}{|c|c|c|c|c|}
\hline $\begin{array}{l}\text { Record } \\
\text { number }\end{array}$ & Species & $\begin{array}{l}\text { Locality, } \\
\text { province }\end{array}$ & Date & Notes \\
\hline 2018-004 & $\begin{array}{l}\text { American Avocet } \\
\text { Recurvirostra americana }\end{array}$ & $\begin{array}{c}\text { Manta- } \\
\text { Montecristi } \\
\text { area, Manabí }\end{array}$ & $\begin{array}{l}15 \text { December } \\
2017\end{array}$ & $\begin{array}{l}\text { Probably mis-identified; } \\
\text { insufficient description. }\end{array}$ \\
\hline $2018-030$ & $\begin{array}{l}\text { Pavonine Quetzal } \\
\text { Pharomachrus pavoninus }\end{array}$ & $\begin{array}{l}\text { La Josefina, } \\
\text { Pichincha }\end{array}$ & 20 August 2018 & $\begin{array}{l}\text { Mis-identified Crested Quetzal } \\
\text { P. antisianus. }\end{array}$ \\
\hline 2019-006 & $\begin{array}{l}\text { Golden-headed Quetzal } \\
\text { Pharomachrus auriceps }\end{array}$ & $\begin{array}{l}\text { Parque } \\
\text { Guápulo, } \\
\text { Pichincha }\end{array}$ & April 2019 & $\begin{array}{l}\text { Mis-identified Crested Quetzal } \\
\text { P. antisianus. }\end{array}$ \\
\hline 2019-021 & $\begin{array}{l}\text { Purple Martin Progne } \\
\text { subis }\end{array}$ & $\begin{array}{l}\text { La Lobería, } \\
\text { San Cristóbal, } \\
\text { Galápagos }\end{array}$ & 12 January 2019 & $\begin{array}{l}\text { Mis-identified young Barn } \\
\text { Swallow Hirundo rustica. }\end{array}$ \\
\hline 2018-008 & $\begin{array}{l}\text { Chestnut-collared } \\
\text { Swallow Petrochelidon } \\
\text { rufocollaris }\end{array}$ & $\begin{array}{c}\text { Meseta de } \\
\text { Gualpi, vía } \\
\text { Chical, Carchi }\end{array}$ & $\begin{array}{l}24 \text { February } \\
2018\end{array}$ & $\begin{array}{l}\text { Mis-identified young Blue-and- } \\
\text { white Swallow Pygochelidon } \\
\text { cyanoleuca. }\end{array}$ \\
\hline 2018-032 & $\begin{array}{l}\text { Darwin-Finch Geospiza } \\
\text { sp. }\end{array}$ & $\begin{array}{l}\text { Milagro, } \\
\text { Guayas }\end{array}$ & October 2018 & $\begin{array}{l}\text { Mis-identified young Shiny } \\
\text { Cowbird Molothrus bonariensis }\end{array}$ \\
\hline
\end{tabular}

\section{Invalidated record}

Saffron-headed Parrot Pyrilia pyrilia. There are five undocumented sightings in Ecuador. Ridgely \& Greenfield (2001) discuss two of them: a pair observed by J. C. Matheus at Salto del Bravo in 1992 and 20 individuals observed by F. Sornoza near Pedro Vicente Maldonado in 1998. Later records include one individual believed seen at Estero Capulí, in Chachi indigenous territory, Esmeraldas province, by the Santiago-Ónzole rivers, by A. Solano-Ugalde. Additional observations, with little further details, were reported by Benítez \& Matheus (1997) and Benítez et al. (1997).

After observing Pyrilia pyrilia in Colombia and juvenile Rose-faced Parrot P. pulchra in Colombia and Ecuador, A. Solano-Ugalde retracted his original identification. Juvenile $P$. pulchra has yellowish brown head, 
not the intense rich yellow of $P$. pyrilia, but light conditions can mislead identification. Likewise, P. Greenfield discussed the first record of this species in Ecuador with the late J. C. Matheus, who admitted a potential confusion with juvenile $P$. pulchra, whereas F. Sornoza also conceded that misidentified juveniles could have been involved in his record.

None of the observers involved mentioned important field marks to separate these two species: red underwing coverts and yellow 'shoulder' patches (Hilty \& Brown, 1986), and likely used the color of the head as the single identification character. As further discussed by Jahn (2011), "freshly fledged juveniles of $P$. pulchra have basically yellowish-brown heads... much like adults of $P$. pyrilia". He further argues that "under certain light conditions, e.g., when the sunlight reflects on the crown and hind neck, distant or fast-flying adults of $P$.pulchra may look almost golden-headed and can be easily confused with $P$. pyrilia".

Since there are no definite records of $P$. pyrilia in a well-surveyed area like Playa de Oro, Esmeraldas province (Jahn, 2011), as well as anywhere else in the lowlands of western Pichincha, where bird observation is a regular activity by residents and visitors alike, we regard all records as unproven. Juan C. Matheus obtained observations reported by Benítez \& Matheus (1997) and Benítez et al. (1997) in short visits to Charco Vicente and Estero Pote, two localities well studied by O. Jahn and P. Mena-Valenzuela (see Jahn, 2011). Since J. C. Matheus dismissed his other record at Salto del Bravo, it is plausible that these records at Charco Vicente and Estero Pote also involved misidentified $P$. pulchra.

There are no records south of the Río San Juan in Cauca Department, western Colombia (Ayerbe-Quiñones, 2018), c. $360 \mathrm{~km}$ north-northwest of the Ecuadorian border. The species is not known to engage in seasonal migrations and, therefore, should not be expected to occur in Ecuador as a vagrant. In light of the distance from known populations and the fact that the Ecuadorian sightings most likely involved misidentified individuals, CERO removes $P$. pyrilia from the Ecuador bird list.

\section{Undocumented, published records}

A few undocumented Ecuador records have been considered valid in previous publications (Ridgely \& Greenfield, 2001; McMullan \& Navarrete, 2017; Freile \& Restall, 2018). Some records, albeit undocumented, have been accepted as valid without hesitation (e.g., Pale-billed Hornero Furnarius torridus; Ridgely \& Greenfield, 2001), while others have been maintained on the country checklist due to lack of evidence to prove them erroneous, as has been the practice of CERO in previous reports (Nilsson et al., 2014; Freile et al., 2017, 2019a). In the following accounts, we review some controversial published records, all of which lack documentation and may well turn out to be invalid due to misidentifications or imprecise locations. Decisions upon records of the following species are pending until receiving a formal proposal to remove them from the Ecuador's list or to revise their status in the country.

Green-tailed Goldenthroat Polytmus theresiae. There are two specimens (male and female) collected at Laguna de Siguin, Pastaza province (Berlioz, 1937), a locality long considered imprecise (Ridgely \& Greenfield, 2001) and even asserted to be in Peru (Ridgely \& Cooper, 2011). There is a site named Siguin north of Río Pastaza, $c .25 \mathrm{~km}$ southeast of Puyo, but elevation and habitat there seem inappropriate for the species (Table 1). However, there are records in northern Peru along the lower Pastaza drainage (Schulenberg et al., 2007) that might suggest its presence on the Ecuadorian side of the Pastaza. Fide P. J. Greenfield, some observers argued that it might be present in the Kapawi area, Pastaza. Until presence/absence in this area is proven, the species remains as hypothetical/undocumented.

Rufous-crested Coquette Lophornis delattrei. There is a single sight record of a pair seen at Jatun Sacha, Napo province, by B. Bochan on 19-25 April 1992 (Ridgely \& Greenfield, 2001). Identification criteria to distinguish this species from Spangled Coquette L. stictolophus are still evolving (Ridgely \& Cooper, 2011). Thus, the fact that few field guides were available by 1992 (Hilty \& Brown, 1986), coupled with a deficient knowledge of these species' distributions, suggests a possible misidentification. Given that the observer did not provide field notes and descriptions of her sightings, it remains impossible to determine the validity of this record. There are no further reports of L. delattre $i$ from Jatun Sacha and other areas at similar elevations, and with similar habitats, whereas L. stictolophus is regularly recorded in Reserva Ecológica Tamandua and Aguayacu, only $47 \mathrm{~km}$ southwest and $26 \mathrm{~km}$ northwest of Jatun Sacha, respectively, albeit at higher elevations (eBird, 2020). It should be noted that seasonal altitudinal movements have been reported for L. delattrei (McMullan, 2016). 
Blue-tufted Starthroat Heliomaster furcifer. There is a single sight record of an apparent immature male by R. S. R. Williams at La Selva, Sucumbíos province, in December 1994 (Ridgely \& Greenfield, 2001; or December 1996 fide R. S. R. Williams, in litt., June 2020). The apparent lack of supporting evidence, field notes, or descriptions has made some experts (N. Krabbe, R. S. Ridgely, N. Athanas) suggest that the record is not valid (see also Ridgely \& Cooper, 2011). However, according to the observer, this record was supported by field notes and a field sketch sent to R. S. Ridgely a few days after fieldwork.

It has been suggested that the species, which ranges from southern Brazil south through northern Argentina (McMullan, 2016), performs some sort of post-breeding migration (Mazzoni \& Perillo, 2014). Nonetheless, the date of the purported observation at La Selva does not fit into an austral migration pattern since the species is reported to breed from November to March (Schuchman et al., 2020). There is one additional unproven sighting by X. Amigo nearby Río Bigal Reserve, Orellana province (see Freile \& Restall, 2018), but the description is insufficient to validate identification. Robert S. R. Williams (in litt., June 2020) felt confident at the time about his identification in the field, but now believes he cannot be $100 \%$ certain that he did not make a mistake. A study of the purported notes and sketch done in the field is pending. However, we believe this species should be removed from the country list since there are no definitive records.

Sapphire-spangled Emerald Amazilia lactea. A single sight record involves a presumed male seen by R. S. Ridgely and F. Sornoza in a swampy area along the Maxus road, Orellana province (Ridgely \& Greenfield, 2001). According to N. Krabbe (in litt., January 2008), R. S. Ridgely later admitted his doubt about this sighting since he has subsequently observed Glittering-throated Emerald Amazilia fimbriata showing bluish-tinged underparts. Although the species is known to engage in local seasonal movements (McMullan, 2016), it is not known from nearby areas in Loreto department, Peru (Schulenberg et al., 2007). The species is transferred to the genus Chionomesa by Remsen et al. (2020).

Rusty-faced Parrot Hapalopsittaca amazonina. The only existing record involves one pair observed by G. H. Rosenberg at Cerro Mongus, Carchi province in March 1992-and identified by distribution (Ridgely \& Greenfield, 2001). Intensive fieldwork at nearby Guandera Reserve (i.e., 10-12 simultaneous field observers during three consecutive sampling months; Cresswell et al., 1999) failed to detect this species, as well as many repeated visits to Cerro Mongus by several observers (eBird, 2020). The nearest locality for the species is Laguna La Cocha, Nariño department, Colombia, c. $110 \mathrm{~km}$ northeast of Cerro Mongus (Harding, 2016). Even though G. H. Rosenberg's record could have involved a wandering pair, no movements are reported for the species (Collar \& Boesma, 2020) and its close relative, the Red-faced Parrot H.pyrrhops, is known to be mostly sedentary (Toyne \& Flanagan, 1997).

Gary H. Rosenberg (in litt., June 2020) considers it appropriate to retract his original identification, although the original description in his field notes fits an Hapalopsittaca. Either further discussion on this species' status or a formal proposal to remove it from the country's list is needed.

Cinereous Finch Piezorina cinerea. A single sight record exists, near El Empalme, Loja province, by B. Whitney on 15 March 1990, with no further observations despite numerous visits to adequate habitat reported by Ridgely \& Greenfield (2001) and carried on subsequently by several observers. Niels Krabbe (in litt., January, 2008) suggested that this record might correspond to an escaped bird, since it is a common cage-bird in Tumbes, Peru. However, vagrancy could have also been involved (Ridgely \& Greenfield, 2001). Field notes taken by B. M. Whitney suggests a protracted observation that theoretically should have permitted a correct identification (Fig. 6).

While the nearest localities for the species to El Empalme lie c. $80 \mathrm{~km}$ west and south, respectively, and $15 \mathrm{~km}$ west and $50 \mathrm{~km}$ south of the nearest Ecuadorian border (eBird, 2020), there are also records further west, near the coast, only 2-3 km south of the Ecuadorian border, implying that the species might eventually be recorded again in Ecuador. Degradation of habitat structure driven primarily by historical and recent land use changes are reported as drivers of variation in the distribution and abundance of Tumbesian species (Devenish et al., 2017). These changes can allow species that are tolerant of degraded habitats, such as Piezorina cinerea, to colonize new areas as their local abundances increase and their ranges expand. 


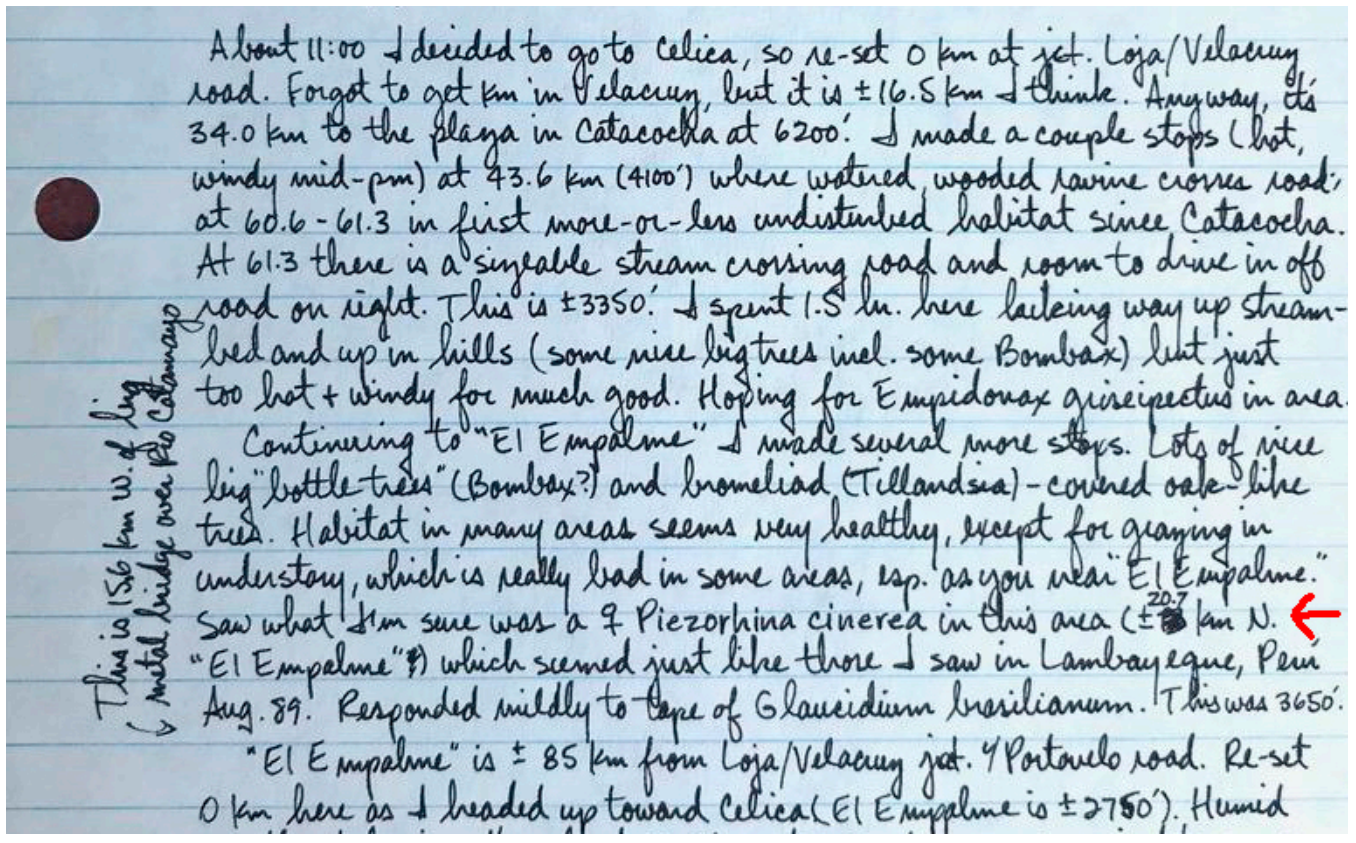

Figure 6: Fragment of field notebook by B. M. Whitney of the single sight record of Cinereous Finch Piezorina cinerea in Ecuador.

\section{ACKNOWLEDGEMENTS}

We thank all observers who submitted their records to CERO (see under species accounts) and to all eBird users for uploading checklists and sharing many remarkable records with us. The committee is grateful for consultations on identification of certain species provided by N. Krabbe, S. N. Howell, B. Haase, and A. Jaramillo. We are likewise indebted to Robert S. Williams, Bret M. Whitney, Xavier Amigo, Gary Rosenberg, and specially to Juan José Álava for sharing field information and comments on different species. Additional thanks go to our fellow CERO members Mitch Lysinger and Robert Ridgely for all their collaboration over the years, and to Kerem A. Boyla for his help organizing Ecuador's lists. Finally, we thank our institutions and tour operators for allowing us to take regular field trips. Niels Krabbe and José María Loaiza provided insightful comments to an earlier version of this manuscript.

\section{REFERENCES}

Ahlman, R. (2015, February 16). eBird checklist: https://ebird.org/view/checklist/S21922130. eBird: an online database of bird distribution and abundance. Ithaca, NY: Cornell Lab of Ornithology. URL: https://ebird.org

Ahlman, R. (2015, July 7). eBird checklist: https://ebird.org/view/checklist/S24179413. eBird: an online database of bird distribution and abundance. Ithaca, NY: Cornell Lab of Ornithology. URL: https://ebird.org

Ahlman, R. (2015, November 6). eBird checklist: https://ebird.org/view/checklist/S25723145. eBird: an online database of bird distribution and abundance. Ithaca, NY: Cornell Lab of Ornithology. URL: https://ebird.org

Ahlman, R. (2015, November 7). eBird checklist: https://ebird.org/view/checklist/S25740519. eBird: an online database of bird distribution and abundance. Ithaca, NY: Cornell Lab of Ornithology. URL: https://ebird.org

Ahlman, R. (2016, December 30). eBird checklist: https://ebird.org/view/checklist/S33288703. eBird: an online database of bird distribution and abundance. Ithaca, NY: Cornell Lab of Ornithology. URL: https://ebird.org

Ahlman, R. (2017, October 30). eBird checklist: https://ebird.org/view/checklist/S40208789. eBird: an online database of bird distribution and abundance. Ithaca, NY: Cornell Lab of Ornithology. URL: https://ebird.org 
Ahlman, R. (2018, May 06). eBird checklist: https://ebird.org/view/checklist/S45366969. eBird: an online database of bird distribution and abundance. Ithaca, NY: Cornell Lab of Ornithology. URL: https://ebird.org

Ahlman, R. (2018, June 12). eBird checklist: https://ebird.org/view/checklist/S46501422. eBird: an online database of bird distribution and abundance. Ithaca, NY: Cornell Lab of Ornithology. URL: https://ebird.org

Ahlman, R. (2018, May 07). XC415656 White-throated Kingbird, Tyrannus albogularis. Xeno-Canto. URL: www.xeno-canto.org/415656

Álava, J.J., \& Carvajal, R. (2005). First records of elephant seals on the Guayaquil Gulf, Ecuador: on the occurrence of either a Mirounga leonina or M. angustirostris. LAJAM, 4(2), 195-198. DOI: http://dx.doi.org/10.5597/lajam00086

Arias-Cruzatty, D. (2015, February 11). eBird checklist: https://ebird.org/view/checklist/S21775984. eBird: an online database of bird distribution and abundance. Ithaca, NY: Cornell Lab of Ornithology. URL: https://ebird.org

Ayerbe-Quiñones, F. (2018). Guía ilustrada de la avifauna colombiana. Bogotá, Colombia: Wildlife Conservation Society.

Ball-Damerow, J.E., Brenskelle, L., Barve, N., Soltis, P.S., Sierwald, P., Bieler, R., LaFrance, R., Ariño, A.H., \& Guralnick, R.P. (2019) Research applications of primary biodiversity databases in the digital age. PLoS ONE, 14(9), e0215794. DOI: https://doi.org/10.1371/journal.pone.0215794

Bayraktarov, E., Ehmke, G., O’Connor, J., Burns, E.L., Nguyen, H.A., McRae, L., Possingham, H.P., \& Lindenmayer, D.B. (2019). Do big unstructured biodiversity data mean more knowledge? Frontiers in Ecology and Evolution, 6, 239. DOI: https://doi.org/10.3389/fevo.2018.00239

Benítez, V., \& Matheus, J.C. (1997). Diversidad y abundancia relativa de las aves en dos localidades en Playa de Oro, zona de amortiguamiento de la Reserva Ecológica Cotacachi-Cayapas, Esmeraldas, Ecuador. In P.A. Mena, A. Soldi, R. Alarcón, C. Chiriboga \& L. Suárez (Eds.), Estudios biológicos para la conservación. Diversidad, ecología y etnobiología (pp. 87-107). Quito, Ecuador: EcoCiencia.

Benítez, V., Canaday, C. \& Matheus, J.C. (1997). Diversidad y abundancia relativa de las aves en dos localidades en San Miguel, zona de amortiguamiento de la Reserva Ecológica Cotacachi-Cayapas, Esmeraldas, Ecuador. In P.A. Mena, A. Soldi, R. Alarcón, C. Chiriboga \& L. Suárez (Eds.), Estudios biológicos para la conservación. Diversidad, ecología y etnobiología (pp. 125-145). Quito, Ecuador: EcoCiencia.

Berlioz, J. (1937). Étude d'une collection d'oiseaux de l'Équateur oriental (Mission Flornoy). Bulletin du Muséum National d'Histoire Naturelle Paris, 9, 354-361. URL: https://www.biodiversitylibrary.org/item/216867\#page/386/mode/1up

BirdLife International. (2020). Species factsheet: Pelecanoides garnotii. Cambridge, UK: BirdLife International. URL: http://www.birdlife.org on 24/11/2020

Bonet, M. (2019, March 10). eBird checklist: https://ebird.org/view/checklist/S57343882. eBird: an online database of bird distribution and abundance. Ithaca, NY: Cornell Lab of Ornithology. URL: https://ebird.org

Bourdin, P. (2018, June 24). eBird checklist: https://ebird.org/view/checklist/S46770858. eBird: an online database of bird distribution and abundance. Ithaca, NY: Cornell Lab of Ornithology. URL: https://ebird.org

Brinkhuizen, D. (2014, December 20). eBird checklist: https:/ebird.org/view/checklist/S64751555. eBird: an online database of bird distribution and abundance. Ithaca, NY: Cornell Lab of Ornithology. URL: https://ebird.org

Brooke, M. de L. (2004). Albatrosses and petrels across the World. Oxford, UK: Oxford University Press. 
Cadena-Ortiz, H., Escobar, J., Cordero, J., Moreno, E., \& Ríos-Alvear, G. (2018). Noteworthy records of Sunbittern Eurypyga helias (Pallas, 1781) (Eurypygiformes, Eurypygidae) and Black-necked Stilt Himantopus mexicanus (Satitus Müller, 1776) (Charadriiformes, Recurvirostridae) from the southern Andes of Ecuador. Check List, 14(5), 801-804. DOI: https://doi.org/10.15560/14.5.801

Camacho, C., \& Torres, S. (2011). First record of Brown Noddy Anous stolidus from the South American Pacific coast. Cotinga, 33: 115-117.

Carboneras, C., Jutglar, F., \& Kirwan, G.M. (2020). Peruvian Diving-Petrel (Pelecanoides garnotii), version 1.0. In J. del Hoyo, A. Elliott, J. Sargatal, D.A. Christie, \& E. de Juana (Eds.), Birds of the World. Ithaca, NY: Cornell Lab of Ornithology. DOI: https://doi.org/10.2173/bow.pedpet1.01

Carrasco, A. (2016, December 29). eBird checklist: https://ebird.org/view/checklist/S49104076. eBird: an online database of bird distribution and abundance. Ithaca, NY: Cornell Lab of Ornithology. URL: https://ebird.org

Clay, R.P. (1999). The first record of Dickcissel Spiza americana for Ecuador. Cotinga, 11, 49. URL: https://www.neotropicalbirdclub.org/wp-content/uploads/2016/02/Cotinga-11-1999-49.pdf

Clements, J.F., Schulenberg, T.S., Iliff, M.J., Billerman, T.A., Fredericks, T.A., Sullivan, B.L., \& Wood, C.L. (2019, March 20). The eBird/Clements checklist of birds of the world: v2019. Ithaca, NY: Cornell Lab of Ornithology. URL: http://www.birds.cornell.edu/clementschecklist/download

Collar, N.J., \& Boesma, P. (2020). Rusty-faced Parrot (Hapalopsittaca amazonina), version 1.0. In J. del Hoyo, A. Elliott, J. Sargatal, D.A. Christie, \& E. de Juana (Eds.), Birds of the World. Ithaca, NY: Cornell Lab of Ornithology. DOI: https://doi.org/10.2173/bow.rufpar2.01

Cresswell, W., Hughes, M., Mellanby, R., Bright, S., Catry, P., Chaves, J., Freile, J., Gabela, A., Martineau, H., MacLeod, R., McPhie, F., Anderson, N., Holt, S., Barabas, S., Chapel, C., \& Sánchez, T. (1999). Densities and habitat preferences of Andean endemic birds in pristine and degraded habitats in northeastern Ecuador. Bird Conservation International, 9(2), 129-145. DOI: https://doi.org/10.1017/S0959270900002252

Devenish, C., Buchanan, G.M., Smith, G.R., \& Marsden, S.J. (2017). Extreme and complex variation in rangewide abundances across a threatened Neotropical bird community. Diversity and Distributions, 23(8), 910-921. DOI: https://doi.org/10.1111/ddi.12577

eBird. (2020). eBird: an online database of bird distribution and abundance. Ithaca, NY: Cornell Lab of Ornithology. URL: https://ebird.org

Espinosa, R. (2015, October 25). eBird checklist: https://ebird.org/view/checklist/S26812447. eBird: an online database of bird distribution and abundance. Ithaca, NY: Cornell Lab of Ornithology. URL: https://ebird.org

Figueroa, J. (2013). The birds of Lobos de Tierra Island, Peru: a review and new records (1684-2011). Revista Brasileira de Ornitologia, 21(1), 58-74. URL: http://revbrasilornitol.com.br/BJO/article/view/0550/pdf 564

Fjeldså, J. \& Krabbe, N. (1990). Birds of the High Andes. Copenhagen, Denmark: Zoological Museum, University of Copenhagen \& Apollo Books.

Freile, J. \& Restall, R. (2018). Birds of Ecuador. London, UK: Helm Field Guides.

Freile, J.F., Brinkhuizen, D.M., Solano-Ugalde, A., Greenfield, P.J., Ahlman, R., Navarrete, L., \& Ridgely, R.S. (2013). Rare birds in Ecuador: first annual report of the Bird Committee of Ecuadorian Records in Ornithology (CERO). Avances en Ciencias e Ingenierías, 5, B24-B41. DOI: http://dx.doi.org/10.18272/aci.v5i2.135 
Freile, J.F., Krabbe, N., Piedrahita, P., Buitrón-Jurado, G., Rodríguez-Saltos, C.A., Ahlman, F., Brinkhuizen, D.M., \& Bonaccorso, E. (2014). Birds, Nangaritza River Valley, Zamora Chinchipe Province, southeast Ecuador: update and revision. Check List, 10(1), 54-71. DOI: https://doi.org/10.15560/10.1.54

Freile, J.F., Solano-Ugalde, A., Brinkhuizen, D.M., Greenfield, P.J., Lysinger, M., Nilsson, J., Navarrete, L., \& Ridgely, R.S. (2017). Rare birds in Ecuador: third report of the Committee for Ecuadorian Records in Ornithology (CERO). Revista Ecuatoriana de Ornitología, 2, 8-27. DOI: http://dx.doi.org/10.18272/reo.v0i1.446

Freile, J.F., Solano-Ugalde, A., Kenefick, M., Lees, A., Piacentini, V.Q., Sandoval, L. Valqui, T., AnguloPratolongo, F., Miranda, J., Claessens, O. \& Sharpe, C.J. (2018). An overview of bird records committees in the Neotropics. Neotropical Birding, 23, 68-75.

Freile, J.F., Solano-Ugalde, A., Brinkhuizen, D.M., Greenfield, P.J., Lysinger, M., Nilsson, J., Navarrete, L. \& Ridgely, R.S. (2019). Fourth report of the Committee for Ecuadorian Records in Ornithology (CERO) and a revision of undocumented and erroneous records in the literature. Revista Ecuatoriana de Ornitología, 5, 5279. DOI: https://doi.org/10.18272/reo.vi5.1277

Freile, J.F., Santander-G., T., Jiménez-Uzcátegui, G., Carrasco, L., Cisneros-Heredia, D., Guevara, E.A., Sánchez-Nivicela, M., \& Tinoco, B.A. (2019). Lista roja de las aves del Ecuador. Quito, Ecuador: Aves y Conservación, Comité Ecuatoriano de Registros Ornitológicos, Fundación Charles Darwin, Universidad del Azuay, Red Aves Ecuador \& Universidad San Francisco de Quito.

Freile, J.F., Athanas, N., Brinkhuizen, D.M., Greenfield, P.J., Lysinger, M., Navarrete, L., Nilsson, J., Olmstead, S., Ridgely, R.S., Sánchez-Nivicela, M., Solano-Ugalde, A., Ahlman, R., \& Boyla, K.A. (2020, July 20). Lista oficial de las aves del Ecuador. Quito, Ecuador: Comité Ecuatoriano de Registros Ornitológicos. URL: http://www.ceroecuador.wordpress.com

García-Godos, I., \& Goya, E. (2006). Diet of the Peruvian Diving Petrel Pelecanoides garnotii at La Vieja Island, Peru, 1997-2000: potential fishery interactions and conservation implications. Marine Ornithology, 34, 33-41. URL: http://www.marineornithology.org/PDF/34 1/34 1 33-41.pdf

Gelis, R. (2012, May 20).eBird checklist: https://ebird.org/view/checklist/S14874059. eBird: an online database of bird distribution and abundance. Ithaca, NY: Cornell Lab of Ornithology. URL: https://ebird.org

Geoffray, P. (2012, March 12) eBird checklist: https://ebird.org/checklist/S12696494. eBird: an online database of bird distribution and abundance. Ithaca, NY: Cornell Lab of Ornithology. URL: https://ebird.org

Granizo, T., Pacheco, C., Ribadeneira, M.B., Guerrero, M., \& Suárez, L. (Eds.). (2002). Libro rojo de las aves del Ecuador. Quito, Ecuador: Simbioe, Conservación Internacional, EcoCiencia, Ministerio del Ambiente \& UICN.

Groenendijk, K. (2018, February 27). eBird checklist: https://ebird.org/checklist/S43253594. eBird: an online database of bird distribution and abundance. Ithaca, NY: Cornell Lab of Ornithology. URL: https://ebird .org

Haase, B. (2011). Aves marinas de Ecuador continental y acuáticas de las piscinas artificiales de Ecuasal. Guayaquil, Ecuador: Aves \& Conservación, BirdLife International \& Ecuasal S. A.

Haase, B. (2019). Aves marinas y costeras de Ecuador, las piscinas de Ecuasal y las islas Galápagos. Cuenca, Ecuador: Ecuasal S. A., Conservación Internacional, Canadian Wildlife Service, Fundación Jocotoco \& Museo de Ballenas.

Harding, J. (2016, November 21). eBird checklist: https://ebird.org/view/checklist/S32687157. eBird: an online database of bird distribution and abundance. Ithaca, NY: Cornell Lab of Ornithology. URL: https://ebird.org 
Hertzog, L. (2015, October 3) eBird checklist: https://ebird.org/checklist/S25290237. eBird: an online database of bird distribution and abundance. Ithaca, NY: Cornell Lab of Ornithology. URL: https://ebird.org

Hilty, S.L., \& Brown, W.L. (1986) A guide to the birds of Colombia. Princeton, NJ: Princeton University Press.

Howell, S.N.G., \& Zufelt, K. (2019). Oceanic birds of the world. A photo guide. Princeton, NJ: Princeton University Press.

Howell, S.N.G, Lewington, I., \& Russell, W. (2014). Rare birds of North America. Princeton, NJ: Princeton University Press.

Hudon, J. (2020). Western Tanager (Piranga ludoviciana) version 1.0. In A.F. Poole \& F.B. Gill (Eds.), Birds of the World. Ithaca, NY: Cornell Lab of Ornithology. DOI: https://doi.org/10.2173/bow.westan.01

Jahn, O. (2011). Bird communities of the Ecuadorian Choco: a case study in conservation. Bonn, Germany: Bonner Zoologische Monographien 56. URL: https://www.zobodat.at/pdf/Bonner-ZoologischeMonographien 56 0001-0514.pdf

Jaramillo, A., \& Burke, P. (1999). New world blackbird. The icterids. London, UK: Helm Identification Guides.

Jumbo, D. (2020, February 9) eBird checklist: https://ebird.org/checklist/S64301618. eBird: an online database of bird distribution and abundance. Ithaca, NY: Cornell Lab of Ornithology. URL: https://ebird.org

Koczur, L.M., Green, M.C., Ballard, B.M., Lowther, P.E., \& Paul, R.T. (2020). Reddish Egret (Egretta rufescens), version 1.0. In P.G. Rodewald (Ed.), Birds of the World. Ithaca, NY: Cornell Lab of Ornithology. DOI: https://doi.org/10.2173/bow.redegr.01

Krabbe, N. (2018, April 24). XC414314 Orange-headed Tanager, Thlypopsis sordida chrysopis. Xeno-Canto. URL: www.xeno-canto.org/414314

Krabbe, N., \& Ridgely, R.S. (2010). A new subspecies of Amazilia Hummingbird Amazilia amazilia from southern Ecuador. Bulletin of the British Ornithologists' Club, 130(1), 3-7. URL: https://www.biodiversitylibrary.org/page/47499688\#page/7/mode/1up

L'Heureux, M., Bell, G., \& Halpert, M.S. (2018). ENSO and the tropical Pacific [in 'State of the climate in 2017']. Bulletin of the American Meteorological Society, 99(8), S102-S104. DOI: https://doi.org/10.1175/2018BAMSStateoftheClimate.1

Loaiza, J.M. (2020, May 24). eBird checklist: https://ebird.org/view/checklist/S69614888. eBird: an online database of bird distribution and abundance. Ithaca, NY: Cornell Lab of Ornithology. URL: https://ebird.org

López-Lanús, B., \& Gastezzi, P. (2000). An inventory of the birds of Segua Marsh, Manabí, Ecuador. Cotinga, 13, 59-64. URL: https://www.neotropicalbirdclub.org/wp-content/uploads/2016/02/Cotinga-13-2000-5964.pdf

López-Victoria, M., \& Estela, F. (2007). Una lista anotada de las aves de la isla Malpelo. Ornitología Colombiana, 5, 40-53. URL: http://asociacioncolombianadeornitologia.org/wpcontent/uploads/revista/oc5/malpelo40-53.pdf

Mac, S. (2020, February 4). eBird checklist: https://ebird.org/view/checklist/S52374500. eBird: an online database of bird distribution and abundance. Ithaca, NY: Cornell Lab of Ornithology. URL: https://ebird.org

Martínez A., D., \& Gastezzi A., P. (2014). Registros nuevos de la distribución del canclón (Anhima cornuta) en el suroeste tropical de Ecuador. Ornitología Colombiana, 14, 125-129. URL: http://asociacioncolombianadeornitologia.org/wp-content/uploads/2014/12/MS1213.pdf 
Mazzoni, L.G., \& Perillo, A. (2014). The wintering distribution of the Blue-tufted Starthroat Heliomaster furcifer (Apodiformes: Trochilidae) in Minas Gerais, and its association with Pyrostegia venusta (Bignoniaceae). Atualidades Ornitológicas, 180, 7-9.

McMullan, M. (2016). Field guide to the hummingbirds. Quito, Ecuador: Ratty Ediciones.

McMullan, M., \& Navarrete, L. (2017). Fieldbook of the birds of Ecuador, including the Galapagos islands and common mammals. Quito, Ecuador: Partners for International Birding \& Ratty Ediciones.

Nilsson, J., Freile, J.F., Ahlman, R., Brinkhuizen, D.M., Greenfield, P.J., \& Solano-Ugalde, A. (2014). Rare birds in Ecuador: second annual report of the Committee for Ecuadorian Records in Ornithology (CERO). Avances en Ciencias e Ingenierías, 6, B38-B50. DOI: http://dx.doi.org/10.18272/aci.v6i2.178

Nooner, B. (2018). eBird checklist: https://ebird.org/checklist/S42142497. eBird: an online database of bird distribution and abundance. eBird, Ithaca, NY: Cornell Lab of Ornithology. URL: https://ebird.org

Onley, D., \& Scofield, P. (2017). Albatrosses, petrels and shearwaters of the world. London, UK: Helm Field Guides.

Ordóñez-Delgado, L., \& Freile, J. F. (2019). First records of Koepcke's Screech-Owl Megascops koepckeae (Aves: Strigidae) in Ecuador. Revista Ecuatoriana de Ornitología, 5, 25-29. DOI: https://doi.org/10.18272/reo.vi5.1193

Pacheco, D. (2019, May 24). eBird checklist: https://ebird.org/view/checklist/S57132698. eBird: an online database of bird distribution and abundance. Ithaca, NY: Cornell Lab of Ornithology. URL: https://ebird.org

Páez-Rosas, D., Riofrío-Lazo, M., Ortega, J., Morales J. de D., Carvajal, R., Álava, J.J. (2018). Southern elephant seal vagrants in Ecuador: a symptom of La Niña events? Marine Biodiversity Records, 11, 13. DOI: https://doi.org/10.1186/s41200-018-0149-y

Pozo-Zamora, G.M., Batallas-R., D., Echeverría-Vaca, G., \& Garzón, C. (2015). Observaciones sobre el Zambullidor Grande Podiceps major (Aves: Podicipedidae) en Ecuador, con el primer registro de anidación y la descripción de vocalización. Avances en Ciencias e Ingenierías, 7(1), B1-B4. DOI: https://doi.org/10.18272/aci.v7i1.220

Rasmussen, C. (2017, Feb 25). eBird checklist: https://ebird.org/view/checklist/S34801033. eBird: an online database of bird distribution and abundance. Ithaca, NY: Cornell Lab of Ornithology. URL: https://ebird.org

Remsen, J.V., Areta, J.I., Bonaccorso, E., Claramunt, S., Jaramillo, A., Pacheco, J.F., Robbins, M.B., Stiles, F.G., Stotz, D.F., \& Zimmer, K.J. (2020, February 20). A classification of the bird species of South America. American Ornithologists' Union. URL: http://www.museum.lsu.edu/ Remsen/SACCBaseline.html

Ridgely, R.S., \& Cooper, M. (2011) Hummingbirds of Ecuador. Field guide. Quito, Ecuador: Fundación de Conservación Jocotoco.

Ridgely, R.S., \& Greenfield, P.J. (2001). The birds of Ecuador. Ithaca, NY: Cornell University Press.

Ridgely, R.S., \& Greenfield, P.J. (2006). Aves del Ecuador. Quito, Ecuador: Academia de Ciencias de Philadelphia \& Fundación Jocotoco.

Ridgely, R.S., \& Greenfield, P.J. (2020). The birds of Ecuador, field guide app version 1.0.0. Birds in the Hand LLC.

Rowlett, R.A. (2019, November 29). eBird checklist: https://ebird.org/view/checklist/S61844715. eBird: an online database of bird distribution and abundance. Ithaca, NY: Cornell Lab of Ornithology. URL: https://ebird.org 
Salazar, S. (2018, September 21). eBird checklist: https://ebird.org/view/checklist/S48659878. eBird: an online database of bird distribution and abundance. Ithaca, NY: Cornell Lab of Ornithology. URL: https://ebird.org

Santander G., T., Ágreda, A., \& Lara, A. (2013). Censo neotropical de aves acuáticas 2008-2012. Quito, Ecuador: Aves y Conservación.

Schuchmann, K.L., Boesman, P.F.D., \& Kirwan, G.M. (2020). Blue-tufted Starthroat (Heliomaster furcifer), version 1.0. In J. del Hoyo, A. Elliott, J. Sargatal, D.A. Christie, \& E. de Juana (Eds.), Birds of the World. Ithaca, NY: Cornell Lab of Ornithology. DOI: https://doi.org/10.2173/bow.bltsta2.01

Schulenberg, T.S., Stotz, D.F., \& Rico, L. (2006). Distribution maps of the birds of Peru, version 1.0. Chicago: Environment, Culture \& Conservation (ECCO), The Field Museum. URL: http://fm2.fieldmuseum.org/uw_test/birdsofperu

Schulenberg, T.S., Stotz, D.F., Lane, D.F., O’Neill, J.P. \& Parker, T.A. (2007). Birds of Peru. London, UK: Helm Field Guides.

Seitz, L. (2018, December 28). eBird checklist: https://ebird.org/view/checklist/S51450378. eBird: an online database of bird distribution and abundance. Ithaca, NY: Cornell Lab of Ornithology. URL: https://ebird.org

Swash, A., \& Still, R. (2000). Birds, mammals, and reptiles of the Galapagos Islands, an identification guide. New Haven, NJ: Yale University Press.

Tinoco, B. (2019, April 21). eBird checklist: https://ebird.org/view/checklist/S55222469. eBird: an online database of bird distribution and abundance. Ithaca, NY: Cornell Lab of Ornithology. URL: https://ebird.org

Tizard, R. (2017, December 03). eBird checklist: https://ebird.org/view/checklist/S40915343. eBird: an online database of bird distribution and abundance. Ithaca, NY: Cornell Lab of Ornithology. URL: https://ebird.org

Toyne, E.P., \& Flanagan, J.N.M. (1997). Observations on the breeding, diet and behaviour of the Red-faced Parrot Hapalopsittaca pyrrhops in southern Ecuador. Bulletin of the British Ornithologists Club, 117(4): 257263. URL: https://www.biodiversitylibrary.org/item/123804\#page/303/mode/1up

Valverde-Romero, M. (2006). First record of the endangered Peruvian Diving Petrel Pelecanoides garnotii breeding on Corcovado Island, Peru.Marine Ornithology,34(1), 75-76. URL: http://www.marineornithology.org/PDF/34 1/34 1 75-76.pdf

Vogt, C. (2017, January 4). eBird checklist: https:/lebird.org/view/checklist/S33436469. eBird: an online database of bird distribution and abundance. Ithaca, NY: Cornell Lab of Ornithology. URL: https://ebird.org

de Vries, T. (1980). El Gavilán Caracolero (Rostrhamus sociabilis) en los Andes del Ecuador. Revista de la Universidad Católica, VIII(27), 99-101.

Weller, A.-A. (2000). Biogeography, geographic variation and habitat preference in the Amazilia Hummingbird, Amazilia amazilia Lesson (Aves: Trochilidae), with notes on the status of Amazilia alticola Gould. Journal für Ornithologie, 141, 93-101. URL: https://link.springer.com/article/10.1007/BF01651776

Wells, J.V., \& Childs-Wells, A. (2002). Extreme extralimital summer record of Western Tanager Piranga ludoviciana from Bonaire, Netherlands Antilles. Cotinga, 18, 96-97. URL: https://www.neotropicalbirdclub.org/wp-content/uploads/2016/05/Cotinga-18-2002-96-97.pdf

Wiedenfeld, D.A. (2006). Aves, the Galapagos Islands, Ecuador. Check List, 2, 1-27. DOI: https://doi.org/10.15560/2.2.1 